European Journal of Turkish Studies

Social Sciences on Contemporary Turkey

3 | 2005

THEMATIC ISSUE

Being a MP in contemporary Turkey

\title{
Differences in role orientation among Turkish MPs
}

\author{
Élise Massicard
}

(2) OpenEdition

Journals

Electronic version

URL: http://journals.openedition.org/ejts/499

DOI: $10.4000 /$ ejts.499

ISSN: $1773-0546$

Publisher

EJTS

Electronic reference

Élise Massicard, "Differences in role orientation among Turkish MPs», European Journal of Turkish

Studies [Online], 3 | 2005, Online since 04 March 2015, connection on 16 February 2020. URL : http:// journals.openedition.org/ejts/499; DOI : 10.4000/ejts.499 


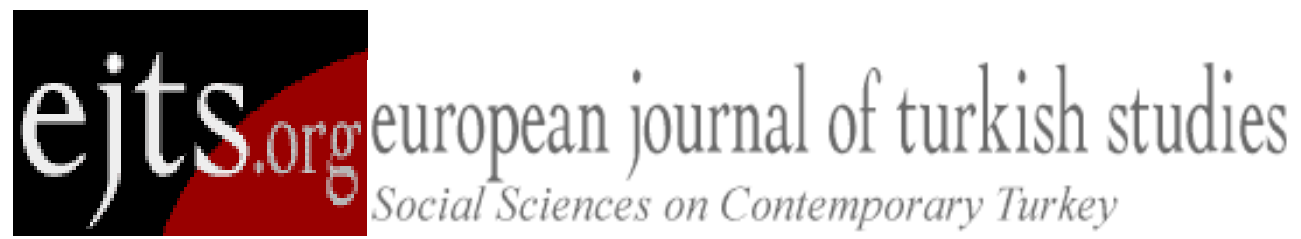

Citation: Massicard, Elise (2005) 'Differences in role orientation among Turkish MPs', European Journal of Turkish Studies, Thematic Issue N³ , Being a MP in contemporary Turkey, URL : http://www.eits.org/document499.html To quote a passage, use paragraph (§).

\title{
Differences in role orientation among Turkish MPs
}

\author{
Elise Massicard
}

\begin{abstract}
Like in many countries, MPs in Turkey are confronted with contradictory role expectations. However, in a context characterized by high turnover, there seems to be no strong standardization of role learning, neither through the main ways of transmission of political roles (party and elected offices) nor through the professionalisation of legislative activity. This statement makes it even more important to take into account each individual's extra-parliamentary experience to understand how the MP roleset is interpreted. The basic assumption is that the way individual MPs invest the role-set is shaped mainly by the resources at their disposal. The qualitative analysis of a limited number of selected cases, resting on observation and in-depth interviews, tends to show that the main factor affecting Turkish MPs' role orientation is their relation with the party. Nonparliamentary (especially professional) skills and relations with the constituency also contribute to shape the MPs' role orientation.
\end{abstract}


Citation: Massicard, Elise (2005) 'Differences in role orientation among Turkish MPs', European Journal of Turkish Studies, Thematic Issue N³, Being a MP in contemporary Turkey, URL : http://www.ejts.org/document499.html To quote a passage, use paragraph (§).

Studies on Turkish MPs have often focused on aggregate data. However, the differences in behaviour and style of individual MPs are a dimension of Turkish political life familiar even to the occasional observer. It seems important to try to grasp these differences in terms of parliamentary roles ${ }^{1}$.

[2] Because the study of parliamentary roles has mainly developed in Western legislatures and more specifically in the US, parliamentary roles have often been defined referring to the US model. More recently, alternative role models have been developed for European countries (Searing (1994) for Great Britain, Andeweg (1997) for the Netherlands). It seems interesting to ask the same questions for Turkey, taking into account the specificities of its institutional system. However, there are few studies devoted to political roles in Turkey (Kalaycıoğlu 1995). It would, therefore, seem too ambitious to develop an alternative model of roles in the limited scope of this study. Rather, we shall address the determinants of role-orientations of Turkish MPs.

[3] In order to understand their role orientation, it seems important to look at the legislators' background. Although it is clearly misleading to infer a direct causal link between social background and legislative role, one may assume that MPs' role orientation is partly the consequence of their previous social trajectories and of their involvement in spaces which are distinct from official politics. MPs act with practical knowledge, technical know-how, ideological orientations and moral convictions that they have acquired during various experiences previous to their investiture. Therefore, drawing mainly on biographic indicators, it seems necessary to analyse the resources at their disposal. Which forms of socialization and involvement have preceded the mandate (family and local socialization, school and university training, career choice, spiritual activities, associative involvement, union and political activism, conditions of entry in political career)? What kind of know-how can they invest and use in political life (Nay 2003: 543)?

[4] In his classical work (1978), Fenno studies what he calls 'home styles', i.e. how legislators act when dealing with their constituents. The author travels with congressmen from all over the US. This article, on the contrary, focuses only on the Parliament, since I did not have the practical possibility to accompany deputies to their constituencies. Therefore, it deals with what can be called

${ }^{1}$ And not in terms of legislative behaviour, which would imply, for example, studying MPs' attendance, their interventions in plenary meetings, their use and the success of law proposals, the content of their political discourse, and their vote. 
Citation: Massicard, Elise (2005) 'Differences in role orientation among Turkish MPs', European Journal of Turkish Studies, Thematic Issue N³, Being a MP in contemporary Turkey, URL : http://www.ejts.org/document499.html To quote a passage, use paragraph (§).

'parliamentary styles'. However, I adopt a broad vision of the Parliament (Abélès 2000; Nay 2003). This work is not limited to the legislative Assembly's official sessions, but includes all the practices that deputies undertake within the framework of their electoral mandate and of the parliamentary institution (plenary sessions, committees, working groups, parliamentary groups, lobbies, etc.) as well as their protracting parliamentary activities outside the Assembly (missions, parliamentary delegations, informal exchanges with interest groups or the bureaucracy) (Nay 2003: 538-539, n. 7). As a matter of fact, elective mandates are not limited to deliberative work. They imply being involved in social work and maintaining links with different audiences both inside and outside the Assembly. Nor is the Assembly isolated from the broader social world. Therefore, I am careful to not look only at the floor of the Chamber. This article aims at trying to link parliamentary role orientation to multiple investments of legislators, in the formal and informal spaces where the career of a representative is being shaped (Nay 2003: 539, 545).

[5] Answering this question does not imply studying all the kinds of elected people: it suffices to observe some of them, the way they act in various situations of interaction (Lagroye 1994). Therefore, even if it draws from existing quantitative data, this study is rather qualitative and inductive. It is inspired by Searing's argument that it is preferable to let the roles emerge from what MPs themselves say about their experiences (Searing 1994:13, 26-28). The main source is in-depth interviews with MPs. Due to the practical difficulty of reaching a larger group who would represent a cross-section of the deputies; I have interviewed a limited number of MPs, thirteen in total. I could not have full control over the sample since the MPs often accepted to be interviewed only if I was being personally introduced to them. Intermediaries - academics ${ }^{2}$ and party groups - had a tendency to introduce me to specific kinds of MPs. This has its importance in terms of role-orientation. Therefore, this research can not claim to offer a representative sample. However, I paid special attention to this bias and tried to correct it by choosing MPs as diverse as possible. The sample includes MPs from different parties, who, in addition, belong to the opposition as well as to the majority. The majority of them is from the current $\left(22^{\text {nd }}\right)$ legislature, but three of them are former MPs (one in the $20^{\text {th }}$, two in the $21^{\text {st }}$ legislature). Two of them had been elected several times, and three have ministerial experience. Therefore, the group includes both long-term politicians and newcomers, with different

2 I owe special thanks to Associate Prof. Dr. Ömer Faruk Gençkaya who helped greatly with the questionnaire and to contact MPs. I would like to thank Amélie Blom-Khan for language revision, Gilles Dorronsoro for commenting previous versions of this paper, as well as Benoit Fliche both for his comments and data processing for table 1. 
Citation: Massicard, Elise (2005) 'Differences in role orientation among Turkish MPs', European Journal of Turkish Studies, Thematic Issue N³, Being a MP in contemporary Turkey, URL : http://www.ejts.org/document499.html To quote a passage, use paragraph (§).

levels of party affiliation. The MPs interviewed were chosen from among various parliamentary committees. The group includes different professional backgrounds (see the main characteristics of interviewed MPs in Appendix 1). The interviews were conducted in Turkish between October 2004 and April 2005. They generally took place in the deputies' offices in the TBMM, sometimes at their office outside the Parliament, in restaurants and/or at their home. Interviews lasted one and a half hour to four hours. When possible, several interviews were conducted with the same person. The names of the MPs are kept anonymous throughout the essay 3 .

[6] Interviews, with open-ended questions, focus on their biographies, social backgrounds, political career, attitudes toward their party and position in the party, personal resources, relations to the constituency, parliamentary activities, and their representation of roles. When possible, informal and 'off-the-record' conversations were conducted with MPs themselves, but also their secretaries and assistants. Whenever it was possible as well, I made observation of their behaviour. Other sources include information collected from documentary sources such as the TBMM's website ${ }^{4}$, albums and newspapers. Besides, most MPs interviewed for this study held very ordered files about their activity as MPs, gather their speeches, law proposals, question motions, press-books, etc. These private archives are quite easily accessible to the researcher and constitute a valuable source. Finally, two interviews were conducted with parliamentary correspondents of national media.

[7] The first part addresses the strong differentiation of roles among Turkish MPs. The second part deals with the three main factors affecting the role orientation of individual MPs: first and foremost their relationship to the party, then their non-partisan, mostly professional, skills and finally the social support they enjoy.

${ }^{3}$ One of them is a woman. However, in order not to make her recognizable, I speak about all of them as 'he'.

${ }^{4}$ It is difficult to get precise and reliable sources on the legislative activities of MPs. Those available through the website of the TBMM (for every MP since the $21^{\text {st }}$ legislature) are those that the party has authorized, therefore they had passed the first institutional step. However, many initiatives are blocked before. 
Citation: Massicard, Elise (2005) 'Differences in role orientation among Turkish MPs', European Journal of Turkish Studies, Thematic Issue N³, Being a MP in contemporary Turkey, URL : http://www.ejts.org/document499.html To quote a passage, use paragraph (§).

\section{A broad and under-standardized role-set?}

\section{Contradictory role-expectations}

[8] According to role theory, a role is the pattern of behaviour and cluster of attitudes expected from persons occupying a given position in a social structure. Wahlke et al. define a legislative role as 'a coherent set of 'norms' of behaviour, which are thought by those involved in the interactions being viewed, to apply to all persons who occupy the position of legislator. It is important to emphasize the normative aspect of the concept (...) The concept postulates that legislators are aware of the norms constituting the role and consciously adapt their behaviour to them in some fashion' (1962: 8).

[9] However, roles are often highly complex and multi-dimensional. According to Merton, each position in a social structure is associated not with a single role, but with a specific 'role-set's. Parliamentarians are an example in point, since they interact with a host of individuals and groups whose 'patterned expectations' of a deputy's role behaviour may vary (Merton 1957:368). As a matter of fact, the role expectations held by parliamentarian peers in the Assembly, by party activists, by constituents or by interest-group representatives may differ from each other, as they may differ from the MP's own definition of his role. Therefore, it appears more relevant to speak about 'role-set' than about one single, coherent role.

Patterned expectations toward Turkish MPs: institutions, parties, media, and audiences

[10] What are the main 'patterned expectations' of a deputy's role in Turkey and where do they come from? The overall structure of the political system constitutes the casting mould in which the roles of MPs are formed. According to the 1982 Constitution (article 80), members of the TBMM represent, not their own constituencies or constituents, but the Nation as a whole. This follows the Burkean conception of a national, rather than local, constituency - even though each deputy has actually been elected by the voters of one particular province (Frey 1965:13).

5 The concept of 'role-set' is to be distinguished from the concept of multiple roles. The latter are associated not with a single social status, but with the various statuses in which individuals operate. Like everyone else, an MP usually holds multiple roles: politician, spouse, parent, conservative and so on. 
Citation: Massicard, Elise (2005) 'Differences in role orientation among Turkish MPs', European Journal of Turkish Studies, Thematic Issue N³, Being a MP in contemporary Turkey, URL : http://www.ejts.org/document499.html To quote a passage, use paragraph (§).

[11] How media construct MPs is of great importance in the formation of role ascriptions, since media constitute the main channel of visibility. How does MPs' exposure to media shape their role-set? It is important to note that Turkish MPs are strongly exposed to the media's scrutiny. Accredited parliament correspondents (parlamento muhabiri) follow almost all legislative activities taking place in the Parliament: plenary sessions, committee meetings, and most of the political group meetings. But they also have access to the backstage (kulis), the place just outside the main floor of the Chamber, where MPs go out of the plenary sessions to make a break or bargain, and where they speak more freely. The kulis is a very good place to grasp news for journalists 6 . It has such an importance that some parties regularly attempt to forbid them access to the kulis ${ }^{7}$. In the end, the Assembly is much more exposed to the media's scrutiny than other institutions (government, bureaucracy or military) ${ }^{8}$. Besides, parliamentary coverage has quite an important place in political news-making. This scrutiny leads to a tight control of MPs' individual behaviour, resulting in strong criticism in case of unruly behaviour ${ }^{9}$ (Aslan-Akman 2005).

[12] Besides being defined by institutions and the media's expectations, the MPs' role-set is also shaped by the expectations emanating from different audiences with which deputies are in contact. As far as constituents are concerned, it is the service and allocational aspects of responsiveness that compose the most frequent demands to MPs (Hazama 2005). Kalaycioğlu argues that the major tasks of a deputy are: promoting the interests of his constituents, protecting them against the challenges of public bureaucracy and providing jobs to his electoral supporters (1995: 48-54). Constituents may ask MPs things which are not among their legal attributions, or even are opposed to them: 'if you explain there are rules to get a visa and don't provide them one, they'll say "this guy was of no use" 10 . As a matter of fact, the very core of being a representative is to interact with various social spheres, which implicates being able to play different roles. Whatever the MP's dominant characteristics are, he has to take into account the plurality of his roles (Lagroye 1994). Turkish MPs - like politicians elsewhere, and maybe more - face contradictory expectations.

\footnotetext{
6 Interview with the head of Hürriyet Parliament office, Ankara, November 1st, 2004.

7 Interview with the chairman of the Parlamento Muhabirleri Derneği, Ankara, November $3^{\text {rd }}, 2004$.

8 This fact might partly explain the lack of confidence of the general public in the Assembly. MPs are often held responsible for all odds, not because they are very powerful, but because they are more exposed to public scrutiny.

${ }^{9}$ For example, in July 2005, two MPs were strongly criticized by all media for having used their guns to shoot in the air during a wedding. This scandal resulted in initiatives to forbid MPs to carry arms. See 'Silah atan milletvekili basını suçladı', Vatan, 27/07/2005.

10 Interview, MP E, Ankara, 24/04/2005.
} 
Citation: Massicard, Elise (2005) 'Differences in role orientation among Turkish MPs', European Journal of Turkish

Studies, Thematic Issue N³, Being a MP in contemporary Turkey, URL : http://www.ejts.org/document499.html

To quote a passage, use paragraph (§).

[13] The role expectations that Turkish MPs face are contradictory because different audiences express them. Yet, even the role expectations carried by the media are contradictory. Parliament correspondents pay attention only to aspects of the MPs' activity that they consider noteworthy and 'newsworthy', i.e. in relation with perceived current policy issues. They maintain relations mainly with MPs who are best informed. These are mainly MPs who already enjoy power positions (being in the bureau of the Assembly, in the party boards, in the direction of party groups, or in committee boards), or MPs who are very active in committee or legislative work. The head of Hürriyet Parliament office declares knowing 100 or $150 \mathrm{MPs}$ because 'they are the people who are continually in the job and are susceptible to produce news. That's why we know them better'11. Most parliament correspondents do not know the other MPs. This means that parliament correspondents put an overstated value on legislative work and MPs engaging in it. In order to appear in public media - which is considered important for re-election by most MPs (Hazama 2005: $§ 19-20$ ) - MPs have to engage in legislative work and advertise about it ${ }^{12}$. Many MPs attempt to inform the correspondents about their legislative activities, for example through press releases. However, when the issue addressed is not on the national agenda, which is most often the case, parliament correspondents ignore them ${ }^{13}$. They also do not cover other MPs' activities, like constituency service or public relation work. Parliament correspondents expect MPs to be in Ankara, involve in legislative work, and act in the name of the Nation, not in the name of their constituency. This is in part because parliament correspondents are working for national channels, newspapers, and press agencies; among them, no local media is represented. In a way, these correspondents - who enjoy a good position in the profession, even among political journalists ${ }^{14}$ - are part of the national elite.

[14] But parliamentary correspondents produce only part of the media coverage on the MPs. Local media do also cover the deputies' activities, but another kind: they cover them mainly in their constituency or when they defend their constituency's interests. They follow the MPs' legislative activities in the parliament only marginally and indirectly, through the news they get from the Anadolu

11 Interview with the head of Hürriyet Parliament office, Ankara, November 1st, 2004.

12 These strategies sometimes undermine legislative work. At its beginning in the mid-1990s, Meclis TV began broadcasting parliamentary activities. The MPs often try to seat in front of the camera (Kocaoğlu 2003: 45). During the committees, which were also broadcast, MPs often tried to speak as long as possible in front of the camera, even if what they said had no much relation to the issue dealt with, which considerably slowed down committee work. Therefore, Meclis TV stopped broadcasting committee meetings live, but gives only some shortcuts.

${ }^{13}$ Observation, Hürriyet Parliament office, Ankara, November $3^{\text {rd }}, 2004$.

14 To become a parliament correspondent, it is necessary to have a press card since more than five years. 
Citation: Massicard, Elise (2005) 'Differences in role orientation among Turkish MPs', European Journal of Turkish Studies, Thematic Issue N³, Being a MP in contemporary Turkey, URL : http://www.ejts.org/document499.html To quote a passage, use paragraph (§).

press agency ${ }^{15}$. Many backbenchers who are not elected from big cities have more relations with local media than with parliament correspondents (like MPs E, G, M) ${ }^{16}$. Local media, on the other hand, view MPs mainly as the representatives of their constituency and defenders of its interest. Thus, there is a quite clear division of labour between local and national media concerning the coverage of MPs activities, local and national journalists having no direct relation with each other. It would be interesting to study further the coverage of MPs' activities by the local and national media. Suffice it here to say that local and national media have different role expectations concerning MPs.

\section{Coping with contradictory role expectations}

[15] How do MPs perceive these contradictory expectations? How do they rationalize their role-set? As a matter of fact, all the MPs I have interviewed declared that they perceived divergent role expectations ${ }^{17}$. In his memoirs, Kocaoğlu states that expectations from the voters and from his party (ANAP) diverged: 'The voter (...) does not ask you what you have done for the European Union. But he wants a weapon permit, he wants a job in the civil service, he wants the appointment or the promotion of somebody from his home region, he wants his nephew who failed the exam to pass in the next class (...) And you, by force, you get busy with these strange affairs. Because if you don't do that, you're considered to be a 'bad MP" (Kocaoğlu 2003: 48). 'In general, the party organisation gives excessive importance to personal advantages and spoil demands' (Kocaoğlu 2003: 27). Later, this former MP also gives room to his conception (or what he wants to appear as his conception) of what a 'good MP' is, which is different from the expectations both of the party and the voters: 'I believe I have been a 'good' MP according to my own standards. For instance, I haven't become a careerist, I haven't acquired property in any unlawful manner, I have realised some of my ideals, I have given priority not to personal, but to collective demands, I have been a good party member' (Kocaoğlu 2003: 20).

15 Interview with the head of Hürriyet Parliament office, Ankara, November 1st, 2004.

${ }^{16}$ Many deputies publish booklets - at the end of every legislative year, or at the end of the legislature - in which they report their legislative activities, and in which they reproduce newspaper cuttings. These booklets aim to produce the image of active MPs, involved in parliamentary work and in the defence of their constituency's interests. Most of the newspaper cuttings I could see in these booklets were taken from local newspapers.

17 No question addressed specifically expectations, but all MPs mentioned the discrepancy between different expectations. 
Citation: Massicard, Elise (2005) 'Differences in role orientation among Turkish MPs', European Journal of Turkish Studies, Thematic Issue N³, Being a MP in contemporary Turkey, URL : http://www.ejts.org/document499.html To quote a passage, use paragraph (§).

[16] Like him, all MPs I interviewed stated a discrepancy between their own representation of their role and what they perceived was expected from them: 'We quarrelled a lot between my inner voice was telling me and what was expected from me. There were some laws about which I suffered much inconvenience (...). Yes, well, the party leader knows what's right, if it is what Turkey needs, then... (...). The ones who come from very professional political backgrounds did not feel any discomfort. People like me, in contrast, did'18. Besides this classical tension between the party line and individual convictions, all interviewed MPs stressed the contradiction between the voters' expectations and their own role representations: 'You will help everybody, everywhere. In reality, this is not something profitable. In my view, a parliamentarian should be limited to conducting his legislative duty. But in Turkey, being a parliamentarian... is perceived as paying attention to all the problems of the voters, and that's what the voters expect from you. If you don't do that (...) the voters erase you, they say it's wrong'19. Many MPs find this to be an important role conflict: 'In my view, the hire and promotion of civil servants should be administered through a central exam (...) But you will invite [the voters] to eat, you will walk around the Parliament with them (...) They enjoy it very much... feeling the state. The one who does that, well, does not make any real work, what he does is contenting others' 20 'The problem there [in the constituency] is that the citizens' understanding of politics is: the MP should come to my village, to my city. But it's not possible (...) 'You have gone to Ankara and you have forgotten us', but the real duty (...) is here, legislation (...) you experience this tension'21.

[17] It would be wrong to assert that the only normative and legitimate role of an MP is that of a legislator or defender of general interest, and that answering the - even personal - demands of citizens is not legitimate. Of course, almost all MPs argue that 'the real duty of an MP is legislation'22, and it is often the image that one wants to give to a Western researcher. However, some MPs - like MPs $A, C, E, G, H, I, L$ in our sample - do not denounce practices like receiving or answering personal demands from citizens, even if they consider them as the result of the state apparatus' dysfunctions. Some of them view these practices as normal, or even as an important part of their role: 'Look, those aren't bad things. Those are the troubles of the citizens, and... the citizen calls you

\footnotetext{
18 Interview, MP B, Ankara, 03/11/2004.

19 Interview, MP A, Ankara, 02/11/2004.

20 Interview, MP B, Ankara, 03/11/2004.

21 Interview, MP H, Ankara, 21/04/2005.

22 Interview, MP G, Ankara, 21/04/2005.
} 
Citation: Massicard, Elise (2005) 'Differences in role orientation among Turkish MPs', European Journal of Turkish Studies, Thematic Issue N³, Being a MP in contemporary Turkey, URL : http://www.ejts.org/document499.html To quote a passage, use paragraph (§).

as the protector of his pains. You must be extremely interested and helpful with them. May be they aren't right. But it is necessary to show some interest'23. Providing - even sometimes individual service (hizmet) to the people is broadly considered to be legitimate (Güneş-Ayata 1994: 61). This activity is even institutionalizedd in the very functioning of the Assembly. Political groups have printed forms called iş takip formu (follow-up form), aiming at rationalizing individual demands, and at dealing with them (see Appendix)24. Receiving visits is considered as being part of the MPs' tasks. According to official sources, in the second legislative year of the 22nd legislature (2003-2004), 690,000 visitors have come to the Parliament at an average of 3,500 visits a day (Anadolu Ajansı 2004) - 30\% less than the previous legislative year, mainly because visit hours have been restricted.

[18] Yet, these different expectations are often perceived as contradictory or even not compatible. Truly they are sometimes: 'The MPs are confronted with a constant traffic of visitors, and they can't spare enough time for legislative activities. The Assembly has taken measures to limit the visits on certain days so that the legislative activities are not affected'25. It's not possible to answer to all the expectations: 'If you want to meet them, you don't have time left for the Parliament. If you don't, you offend the voters and the citizens' 26 . In addition to this time allocation problem, the rules of the game that yield successful results regarding legislative work differ from those that lead to high levels of popularity and public recognition.

[19] How do individual MPs cope with role strain arising from role conflict? There are two possibilities of coping with these diverging role expectations. The first possibility is role-switching, meaning that MPs are switching from one role to another according to different contexts. One may observe the succession of distinct behaviours and ways of being in their everyday practices. The second possibility is role-specialisation, i.e. a kind of 'division of labour' between MPs specializing in different roles and showing different role orientations. Role orientation refers to systematic differences in the legislators' conceptions of a particular component of the legislator's role.

[20] Our hypothesis is that, even if role-switching is present, we can observe a strong internal differentiation in role orientation of Turkish MPs, i.e. in their ways of playing the MP's role-set. As a matter of fact, individual role conceptions of the MPs in our sample show strong differences: they

\footnotetext{
${ }^{23}$ Interview, MP C, Istanbul, 29/10/2004.

24 Observation, direction of AKP group, Ankara, 22/04/2005.

25 Interview, MP G, Ankara, 21/04/2005.

26 Interview, MP A, Ankara, 18/04/2005.
} 
Citation: Massicard, Elise (2005) 'Differences in role orientation among Turkish MPs', European Journal of Turkish Studies, Thematic Issue N³, Being a MP in contemporary Turkey, URL : http://www.ejts.org/document499.html To quote a passage, use paragraph (§).

prioritize the contradicting role expectations in various ways, some have interiorised the hizmet role but others much less: 'We don't have enough strength to work at those things, our work here is legislation and participating in parliamentary activities (...) I felt very uncomfortable [with the citizens' demands], and I reacted against that (...) In that sense, I was a unlikeable MP, but... They still say, I was very respected because I never changed my mind, because I was straight and honest, because I pondered on Turkey and the world (...), because I did not expect any rent from politics, because I did not pursue any private interests, because I was a man with principles. But I can't say that I was appreciated, or that I devoted myself to the service of the voters. Thus - I suffered much inconvenience'27. 'My characteristic is that I always speak to the citizen, I certainly esteem him (...) Even if I can't do anything for him, at least he will depart satisfied from here'28. Starting from these different prioritizations of tasks, I assume that there is considerable scope for different answers to these contradictory expectations, at least for some MPs.

\section{Learning process of roles and socialization}

[21] An important factor in this broad interpretation scope is the pretty poor political socialization - through which legislative norms and roles are internalised - among Turkish MPs. What do the recruitment process and career paths of Turkish MPs indicate in terms of patterns of socialization?

\section{Turnover and previous parliamentary experience}

[22] A first important point is the high turnover in the TBMM, which renews itself by more than $50 \%$ in every election since 1980. The highest turnover took place in 1983 because of the coup (85\%); but it was even higher in 2002 (almost 90\%); in the meantime, it varied between $50 \%$ and $60 \%$, which is also quite high. However, more than the mere turnover rate, the previous parliamentary experience of Turkish MPs seems important to understand the socialization process. It also appears to be quite low, especially in 2002.

27 Interview, MP B, Ankara, 03/11/2004.

28 Interview, MP I, Ankara, 21/04/2005. 
Citation: Massicard, Elise (2005) 'Differences in role orientation among Turkish MPs', European Journal of Turkish

Studies, Thematic Issue N³, Being a MP in contemporary Turkey, URL : http://www.ejts.org/document499.html

To quote a passage, use paragraph (§).

Table 1: MPs with previous parliamentary experience in proportion to the number of seats in the lower chamber of the TBMM (1920-2002)

\begin{tabular}{|l|l|l|}
\hline Assembly & Date & $\%$ \\
\hline I & 1920 & 23 \\
\hline II & 1923 & 37 \\
\hline III & 1927 & 63 \\
\hline IV & 1931 & 71 \\
\hline V & 1935 & 66 \\
\hline VI & 1939 & 68 \\
\hline VII & 1943 & 67 \\
\hline VIII & 1946 & 59 \\
\hline IX & 1950 & 19 \\
\hline X & 1954 & 49 \\
\hline XI & 1957 & 47 \\
\hline XII & 1961 & 16 \\
\hline XIII & 1965 & 49 \\
\hline XIV & 1969 & 47 \\
\hline XV & 1973 & 43 \\
\hline$X V I$ & 1977 & 53 \\
\hline$X V I I$ & 1983 & 9 \\
\hline XXI & 1999 & 45 \\
\hline XXII & 2002 & 19,4 \\
\hline
\end{tabular}

Sources: Frey (1965: 164); Tachau, Good (1973: 555, table 1); Kalaycıoğlu (1988: 51, table 1); Tachau (1988: 108, table 3); TBMM Album. Figures for 1987, 1991 and 1995 could not be calculated.

[23] To the extent that newcomers are inexperienced in legislative politics, their socialization into legislative roles and their adoption of the established norms of legislative conduct are likely to be quite improbable during a single term or two (Kalaycıoğlu 1988: 49). 'High turnover rates of seats in the TGNA, through their undermining influence on the establishment of binding norms of legislative conduct (...), tend to inhibit the professionalisation of deputyship in the TGNA. (...) By professionalisation is meant the development of the role of deputyship into a pattern of actions and a constellation of expectations that are learned or adopted after a lengthy period of service in a legislature, preceded by a period of apprenticeship in a party organization or in the local political machinery, which help one to develop the above-mentioned expectations' (Kalaycıoğlu 1988: 58). Although Kalaycioğlu's paper deals with the 1983 legislature, which is in many regards an exception because of the rupture in political personnel brought by the 1980 coup, his conclusion are probably true as well, with some nuance, for most of the post-1983 period, since newcomers in politics have been numerous since then. 
Citation: Massicard, Elise (2005) 'Differences in role orientation among Turkish MPs', European Journal of Turkish Studies, Thematic Issue N³, Being a MP in contemporary Turkey, URL : http://www.ejts.org/document499.html To quote a passage, use paragraph (§).

Other socialization processes: party organisations and local elective offices

[24] However, as Kalaycıoğlu argues, a political career is not limited to parliamentary experience. There are other instances of socialization and learning of political roles, the main ones being local elective offices and apprenticeship in a party organization. In Germany for example, almost all MPs have a long career as party members, mayors, deputies of local councils, and so on (Saalfeld 1997). This common socialization and learning process leads to some degree of standardization and coherence of MPs' role. Saalfeld argues that the professionalisation of parliamentary roles and the greater importance of career politicians in post-war Germany have behavioural implications: as a result of their relatively similar career patterns, German parliamentarians have been found to share, at least to some extent, certain 'professional' norms. What are the previous experience of Turkish MPs in local elective offices and party organizations? What do they tell us about MPs' socialization and learning of political roles?

[25] For Turkey, we unfortunately have no systematic data. Most studies on this issue have been conducted in the 1960s and 1970s, but not pursued until the present day. Moreover, it is noteworthy that the main source used to produce this indicator, the albums of the TBMM, does not always contain complete data concerning party offices or former local elective offices. Therefore, it is probable that due to the nature of the sources, political experience of MPs in local elective offices and party organisations is underestimated. Another problem is that the sources do not differentiate between previous and present political experience, a very significant difference in terms of political careers. Questionnaires help, to some extent, to fill this gap, but are by definition conducted on one legislature and do not permit the construction of long statistical series. However, all previous works are unanimous in showing poor experience of Turkish MPs, both in local elective offices and in party experience. Let us begin with experience in local elective office. 
Citation: Massicard, Elise (2005) 'Differences in role orientation among Turkish MPs', European Journal of Turkish

Studies, Thematic Issue N³, Being a MP in contemporary Turkey, URL : http://www.ejts.org/document499.html

To quote a passage, use paragraph (§).

Table 2: MPs with previous experience in local elective offices in proportion to the number of seats in the lower chamber of the TBMM (1923-1969)

\begin{tabular}{|c|c|c|}
\hline \hline Assembly & Date & Local elective Offices (in \%) \\
\hline II & 1923 & - \\
\hline III & 1927 & 9 \\
\hline IV & 1931 & 6 \\
\hline V & 1935 & 9 \\
\hline VI & 1939 & 12 \\
\hline VII & 1943 & 11 \\
\hline VIII & 1946 & 12 \\
\hline IX & 1950 & 4 \\
\hline X & 1954 & 10 \\
\hline XII & 1961 & 4 \\
\hline XIII & 1965 & 6 \\
\hline XIV & 1969 & 9 \\
\hline
\end{tabular}

Source: Tachau, Good (1973: 555, Table 1).

[26] The more focused analysis conducted by Oya Çitçi, which is based also on the Parlamenterler Ansiklopedisi (1983), demonstrates how incomplete the TBMM albums are, which is the main source for the above study.

Table 3: MPs with previous experience in local mandates in proportion to the number of seats in the lower chamber of the TBMM (1950-1987)

\begin{tabular}{|c|c|c|c|c|c|c|c|}
\hline Assembly & Date & Mayor & $\begin{array}{l}\text { Member of } \\
\text { municipal } \\
\text { council }\end{array}$ & $\begin{array}{l}\text { Member of } \\
\text { subprovincial } \\
\text { council }\end{array}$ & $\begin{array}{l}\text { City } \\
\text { council }\end{array}$ & \begin{tabular}{|l|l} 
Total \\
\end{tabular} & $\begin{array}{l}\% \text { of MPs } \\
\text { with } \\
\text { experience } \\
\text { in local } \\
\text { offices }\end{array}$ \\
\hline IX & 1950 & 14 & 5 & 8 & - & 27 & 5.54 \\
\hline$X$ & 1954 & 35 & 8 & 17 & 2 & 62 & 11.59 \\
\hline $\mathrm{XI}$ & 1957 & 45 & 12 & 16 & 1 & 74 & 12.19 \\
\hline XII & 1961 & 11 & 3 & 1 & - & 15 & 3.33 \\
\hline XIII & 1965 & 9 & 8 & 5 & - & 22 & 4.89 \\
\hline XIV & 1969 & 17 & 7 & 4 & - & 28 & 6.22 \\
\hline $\mathrm{XV}$ & 1973 & 16 & 6 & 12 & - & 34 & 7.56 \\
\hline $\mathrm{XVI}$ & 1977 & 20 & 7 & 8 & - & 35 & 7.78 \\
\hline $\mathrm{XVII}$ & 1983 & 16 & 10 & 6 & - & 32 & 7.11 \\
\hline XVIIII & 1987 & 33 & 9 & 12 & - & 54 & 11.55 \\
\hline Total & & 214 & 75 & 89 & 3 & 383 & 8.09 \\
\hline
\end{tabular}

Source: Çitçi (1989: 225)

[27] The poor local office experience of Turkish MPs becomes clearer when compared with other countries. In Germany, the average MPs' political career begins with a political 'apprenticeship' 
Citation: Massicard, Elise (2005) 'Differences in role orientation among Turkish MPs', European Journal of Turkish Studies, Thematic Issue N³, Being a MP in contemporary Turkey, URL : http://www.ejts.org/document499.html To quote a passage, use paragraph (§).

of between two and six years as a local councillor. 31\% of the 194 MPs interviewed by Herzog in 1988/1999 had held local electoral office as councillors prior to their election to the Bundestag, 38\% had held such a mandate and continued to hold it after their election to the Bundestag, and only $31 \%$ had never been elected office at local level (Herzog 1990)29. The experience of Turkish MPs in elective offices seems to be low compared also to other European countries, where 'a very large proportion of MPs (from $40 \%$ upwards) had an elective or governing position at local or regional level before entering into the national representative body' (Cotta, Best 2000: 505). How widespread is the experience of MPs in local party offices? It is recognized as a way of learning political roles and facilitating parliamentary socialization by the MPs who, in our sample, had this experience, such as MP G. However, this experience also appears to be quite rare:

Table 4: MPs with previous experience in local party offices in proportion to the number of seats in the lower chamber of the TBMM (1950-1969)

\begin{tabular}{|l|l|l|}
\hline \hline Assembly & Date & $\begin{array}{l}\text { Local Party Offices } \\
\text { (in \%) }\end{array}$ \\
\hline II & 1923 & - \\
\hline III & 1927 & - \\
\hline IV & 1931 & 1 \\
\hline V & 1935 & 2 \\
\hline VI & 1939 & 4 \\
\hline VII & 1943 & 4 \\
\hline VIII & 1946 & 7 \\
\hline IX & 1950 & 8 \\
\hline X & 1954 & 7 \\
\hline XII & 1961 & - \\
\hline XIII & 1965 & 8 \\
\hline XIV & 1969 & 8 \\
\hline
\end{tabular}

Source: Tachau, Good (1973: 555, Table 1).

[28] This table clearly shows that until the 1960s political experience in local party offices among Turkish MPs is very low, though increasing over time. Tachau and Good conclude that 'as a whole, the data [...] suggest that neither local elective offices nor local party offices have been very important as channels of recruitment to the national political elite' (1973:556). But party headquarters

29 These results are similar to those found in earlier studies during the late 1960s. 
Citation: Massicard, Elise (2005) 'Differences in role orientation among Turkish MPs', European Journal of Turkish Studies, Thematic Issue N³, Being a MP in contemporary Turkey, URL : http://www.ejts.org/document499.html To quote a passage, use paragraph (§).

seem more important than local party organizations as a channel of recruitment to the Parliament, as Tachau and Good conclude from more precise data concerning the $1960 \mathrm{~s}^{30}$ :

Table 5: MPs with previous experience in local and national elective and party offices in proportion to the number of seats in the lower chamber of the TBMM (1961-1969)

\begin{tabular}{|l|l|l|l|}
\hline \hline Year & $\begin{array}{l}\text { Local } \\
\text { Elective } \\
\text { Office (in \%) }\end{array}$ & $\begin{array}{l}\text { Local Party } \\
\text { Office (in \%) }\end{array}$ & $\begin{array}{l}\text { National Party } \\
\text { Office (in \%) }\end{array}$ \\
\hline 1961 & 4 & - & 4 \\
\hline 1965 & 6 & 8 & 12 \\
\hline 1969 & 9 & 8 & 17 \\
\hline
\end{tabular}

Source: Tachau, Good (1973: 559, Table 3).

[29] Even if national party organizations seem to constitute a more important channel of recruitment to the Parliament than local offices, experience there does not seem to be very high when compared with other countries. For example, not even $10 \%$ of all German MPs hold no party function at all, whereas $20 \%$ hold positions on the local, $38 \%$ on the district, and $20 \%$ on the national party leadership bodies; on balance, a little less than two-thirds of all German MPs hold positions as chairpersons or as members of the executive committees on the different organisational levels of their party (Patzelt 1997: 58). Gençkaya (2000) has produced the most precise data on the experience of Turkish MPs in local and national party offices, on the basis of a questionnaire conducted on the deputies of the 20th Parliament (1995-1999):

${ }^{30}$ Another important finding of this study is that the proportion of MPs with former experience in elective and party offices strongly varies according to the parties. 
Citation: Massicard, Elise (2005) 'Differences in role orientation among Turkish MPs', European Journal of Turkish Studies, Thematic Issue N³, Being a MP in contemporary Turkey, URL : http://www.ejts.org/document499.html To quote a passage, use paragraph (§).

Table 6: Proportion of MPs interviewed having hold party offices

\begin{tabular}{|l|l|}
\hline Office & $\begin{array}{l}\text { \% of MPs interviewed having hold } \\
\text { this office }\end{array}$ \\
\hline National congress delegate & 31.6 \\
\hline Provincial congress delegate & 27.2 \\
\hline Member of the national party directing committee & 24.6 \\
\hline Provincial party leader & 22 \\
\hline Subprovincial congress delegate & 21.1 \\
\hline Subprovincial party leader & 17.5 \\
\hline Member of the provincial party executive committee & 14.9 \\
\hline Member of the party assembly & 14 \\
\hline Member of the subprovincial party executive committee & 10.5 \\
\hline Party vice-chairman & 8.8 \\
\hline Office holder in a collateral organisation & 7 \\
\hline Secretary of the provincial party executive committee & 6.1 \\
\hline General secretary or vice general secretary & 4.4 \\
\hline Secretary of the subprovincial party executive committee & 3.5 \\
\hline Member of the central discipline committee & 3.5 \\
\hline Provincial supervisor & 2.6 \\
\hline Deputy chair of a party group & 0.9 \\
\hline
\end{tabular}

Source: Gençkaya (2000: 241, table 6).

[30] In this table including both past and present experiences, one and the same MP can have had several party offices (therefore it is difficult to draw comparable data to that of Patzelt). On the whole, $23.6 \%$ of all MPs Gençkaya interviewed had no party function at all; he states that they have on the whole poor experience in party organizations (Gençkaya 2000: 242). Besides, the most widespread party office is that of delegate, which is not very binding.

[31] But this does not indicate precisely the duration of the relation between MPs and parties, during which parties can transmit know-how to their members and office holders. In his survey, Gençkaya obtained the following results about previous party membership of MPs:

Table 7: Duration of party membership among interviewed MPs

\begin{tabular}{|l|l|l|l|l|l|l|l|}
\hline $\begin{array}{l}\text { Duration of membership } \\
\text { in the party }\end{array}$ & ANAP & CHP & DSP & DYP & FP & DTP & Total \\
\hline $0-2$ years & $20 \%$ & $16.7 \%$ & - & $10.6 \%$ & $100 \%$ & $100 \%$ & $43 \%$ \\
\hline $3-5$ years & $24 \%$ & $8.3 \%$ & $85.7 \%$ & $35.7 \%$ & - & - & $21 \%$ \\
\hline $6-10$ years & $4 \%$ & $33.5 \%$ & $14.3 \%$ & $17.9 \%$ & - & - & $9.7 \%$ \\
\hline More than 11 years & $52 \%$ & $41.5 \%$ & - & $35.8 \%$ & - & - & $26.3 \%$ \\
\hline
\end{tabular}

Source: Gençkaya (2000: 240, table 5) 
Citation: Massicard, Elise (2005) 'Differences in role orientation among Turkish MPs', European Journal of Turkish Studies, Thematic Issue N³, Being a MP in contemporary Turkey, URL : http://www.ejts.org/document499.html To quote a passage, use paragraph (§).

[32] The group of long-time party members appears to represent only slightly more than one quarter of the MPs ${ }^{31}$. On the other hand, a strong majority of MPs were party members for less than 5 years, which is congruent with the data given by Kalaycioğlu on the 1983 Parliament, where about one half of the interviewed deputies had never been a member of a socio-political association or of a political party, and only about $32 \%$ pointed out that they were affiliated with a political party since six years or more (Kalaycıoğlu 1988: 59). Although the 1983 Assembly is in many respects an exception, political experience of MPs seems not to have improved much since then. Indeed, party boards do not designate only candidates well tried and experienced in party organizations; longstanding prior party activities are not a condition in candidate selection. Many people are asked by the party direction to become candidates without being party members whatsoever.

[33] Therefore, it would be erroneous to assert that most Turkish MPs' careers follow typical, predictable patterns. In each legislature, there is a relatively high large share of 'outsiders' into the TBMM, who had not previously pursued a political career. 'In conclusion, it can be argued that the majority of the deputies of the [1983] TBMM were catapulted into their legislative roles without any first-hand, prior experience with party politics and without having a lengthy apprenticeship period' (Kalaycıoğlu 1988: 59). There seem to be no strong, institutionalized transmission or learning of MPs' roles during their former experience, neither in party organizations nor in local elective offices. How is it inside the Parliament itself?

\section{Transmission inside the Parliament}

[34] A majority of MPs have obtained some professional skills in 'politics-facilitating occupations' (such as solicitors, civil servants, academics). Some of them had contacts with MPs in their former professional life (as was the case of MPs C, F, I in our sample). Besides, they have already acquired basic political skills during the initial steps of the political career before election during the campaign, at the latest. Then, the parliamentary organisation itself to some extent moulds the roles of MPs seeking re-election and advancement within the hierarchy of party positions. However, a parliamentary newcomer will find himself faced with a set of challenges and expectations

${ }^{31}$ This is congruent with Kalaycıoğlu's finding that 'only a relatively small proportion of about one-quarter or less of the deputies may be referred to as professional political actors' (Kalaycıoğlu 1988: 59). 
Citation: Massicard, Elise (2005) 'Differences in role orientation among Turkish MPs', European Journal of Turkish Studies, Thematic Issue N³, Being a MP in contemporary Turkey, URL : http://www.ejts.org/document499.html To quote a passage, use paragraph (§).

quite unfamiliar to him at first, in terms of political-know-how and roles. How does this learning take place inside the TBMM?

[35] Most of the [1983] deputies were in the process of learning and practising the role of being a legislator at the same time (Kalaycıoğlu 1988: 59). This is also the way all MPs interviewed for this study felt: all of them reported that professional socialization is happening by practising, that is by 'training on the job' (Kocaoğlu 2003). Neither the Assembly, nor the parties organize formation sessions for new MPs, as all interviewed MPs reported. Some party groups organize short briefings. Therefore, the learning of the job and legislative roles in the Assembly occurs in an informal and uninstitutionalized way. For example, some new MPs may ask to senior members MPs what are the rules of the game or, more importantly, observe the way experienced colleagues exercise their work as representatives. Socialization occurs mostly through mimetic practice and distinction.

[36] Other people, such as the members of the Assembly staff, can play an important role in the socialization of new MPs. Turkish MPs have acquired, in recent years, access to more - although not extravagant - personnel resources to perform their job. Every MP has one danışman (advisor) since the beginning of the 1990s, and one secretary. According to the President of the Assembly, the TBMM employed almost 5,000 personnel in 2004 (Anadolu Haber Ajansı 2004)32. Many MPs recognize the importance of people knowing how everything works: 'the people who should help you have to know Ankara's codes well, otherwise they can't be useful' (Kocaoğlu 2003: 44). The MPs can choose freely their assistant, he can also come from outside. MP $L$ has chosen both an assistant and a secretary with parliamentary experience: 'they know the Assembly well. I believe that you must work with people knowing this job professionally. That's the reason why I chose them'33. 'My assistant made preparations in advance on the issues I was working on. For example I have to make a speech, which speeches had been made on this issue before, who had said what (...) he found that, and he found very strategic things. (...) I had a good assistant, but everybody could not expect this work from his'34.

\footnotetext{
${ }^{32}$ As far as I know, there are no detailed studies on parliamentary staff in Turkey.

33 Interview, MP L, Ankara, 25/04/2005.

34 Interview, MP C, Istanbul, 29/10/2004.
} 
Citation: Massicard, Elise (2005) 'Differences in role orientation among Turkish MPs', European Journal of Turkish Studies, Thematic Issue N³, Being a MP in contemporary Turkey, URL : http://www.ejts.org/document499.html To quote a passage, use paragraph (§).

[37] However, parliamentary assistants are not professionals. They have another job: most of them are civil servants in other administrations ${ }^{35}$ and become parliamentary assistants temporarily. 'For me to be here is a bit like an escape from the [Education] ministry'36 says one of them. They were hired as assistants mainly because they had been sympathizers of a party and have acquaintances there (assistant of MP D), or because they knew the MP before through professional or personal contacts (assistants of MP A, B, G, F). MPs have chosen them because they thought they would be useful for legislative work (E, F), for some technical aspect of it (assistant of MP M) or for the relations with the constituency (B). Some assistants do this job to finance their studies in econometrics (like the assistant of MP M). The turnover of assistants seems to be quite high, even in a single legislature: assistants of MPs $A, C$, and M changed during the legislature, mainly because they found better opportunities elsewhere or because their MP was unsatisfied with them.

[38] As a consequence, many assistants ${ }^{37}$ have poor experience of parliamentary work: 'In Turkey, there is no political advisorship (siyasi danışmanlık). In reality, an assistant should prepare the documents related to the laws and to the important activities of the MP (...) Here, it's impossible. The people we call advisors (danışman) do any kind of private service, regulate the relations with the voters, drive the MP here and there, do everything in short. Well, the real function of parliamentary assistant does not exist' ${ }^{38}$. 'Here, the assistant's role (...) is basically to take a bit of the MPs' burden and to help them with public relations. Otherwise, 'I'll prepare a law proposal, find me the relevant documents, prepare a report and then l'll look at that...' There's nothing like that here'39. Many of the MPs I interviewed complaint about the assistants: 'Honestly, this mechanism doesn't work in a very effective way. The so-called advisors (danışman) are generally young people (...). In order to be an advisor, he must have more knowledge than you. But in practice this is not the case, I call them helpers (yardımcI), it's righter'40. Some, like MP C, also complaint about the research service of the Assembly as being inefficient and useless. When he needed documentation or expertise on an issue,

35 The wage given to an assistant from the outside is low (about 1,200 YTL in 2005), whereas civil servants keep their wage in addition to a supplement; this can explain why civil servants are often preferred as assistants (Kocaoğlu 2003: 44).

36 Interview, assistant of MP D, Ankara, 02/11/2004.

37 The Turkish word for parliamentary assistant is danışman, which in other contexts means 'advisor'.

38 Interview, MP B, Ankara, 03/11/2004.

39 Interview, MP B, Ankara, 15/04/2005.

40 Interview, MP H, Ankara, 21/04/2005. 
Citation: Massicard, Elise (2005) 'Differences in role orientation among Turkish MPs', European Journal of Turkish Studies, Thematic Issue N³, Being a MP in contemporary Turkey, URL : http://www.ejts.org/document499.html To quote a passage, use paragraph (§).

he preferred calling specialists working outside of the Assembly he knew before ${ }^{41}$. Because he was dissatisfied with his assistant and could not find anybody convenient in Ankara, MP J hired an assistant he knew before from his constituency, Istanbul, and pays a surplus wage from his own pocket. Some assistants however, after being hired on a temporary base, manage to build specialized knowledge, be recommended and stay in the Parliament serving other MPs, which is the case of the assistant of MP E, who had fifteen years experience in the Assembly before.

[39] It is also the case of some secretaries. Some of them are professional, like MP C's: 'My secretary really made my life easier. Because there's a special ritual of the Assembly, a special jargon. And she knew them'42. However, others are not: 'Actually, I didn't want to work here. I wanted to make an academic career. But this is in the long term. My husband wanted me to work before, that's why I took the exam. This is a general exam for civil service. Afterwards, every institution opens its own exam'43. At the same time, she continues studying French language and literature at the master level. Even after having passed the exam, some secretaries don't have a permanent status, and are brought from other administrations temporarily. In this case, they mostly enter the job through personal relations and recommendations. When the legislature changes, their staying in the Assembly depends on the recommendation of the MP with whom they have been working, whereas for permanent secretaries, the electoral new deal changes only with whom they will work. As access to assistants and secretaries with parliamentary experience and good reputation is a matter of recommendation (Kocaoğlu 2003: 44), MPs having previous connections in the parliament are privileged for finding them, which implies a kind of reproduction effect. For instance, MP L knew from his previous MP mandate an assistant and a secretary with parliamentary experience he chose during his second mandate.

[40] These are only clues, which should be studied further in order to build more precise knowledge. However, our hypothesis is that an important part of the parliamentary staff 44 is not specialised and does not contribute heavily to socialization into parliamentary roles. The employment of specialised staff is an indirect indicator commonly used to measure the tendency of parliamentary

\footnotetext{
41 Interview, MP C, Istanbul, 29/10/2004.

42 Interview, MP C, Istanbul, 29/10/2004.

43 Interview, secretary of MP M, Ankara, 22/04/2005.

44 This is probably different for committee secretaries, who are older and have much more experience in the Parliament than most MPs' secretaries. In the same way, there are party group advisors who have political experience and are able to help MPs in writing speeches. Interview, MP A, Ankara, 18/04/2005.
} 
Citation: Massicard, Elise (2005) 'Differences in role orientation among Turkish MPs', European Journal of Turkish Studies, Thematic Issue N³, Being a MP in contemporary Turkey, URL : http://www.ejts.org/document499.html To quote a passage, use paragraph (§).

politics to be pursued as a professional career. Other indirect measures include the average age at which MPs are first elected to Parliament, the average number of years they spend as MPs - the longer they remain members, the less likely they are to have a significant pre- or post-parliamentary career outside politics. Another important indicator is the degree to which politics becomes their predominant professional occupation (Saalfeld 1997: 38). Is MP a full-time job, like in Germany, where it leaves little time to spare for a non-parliamentary career? Or can it also be a 'retirement job' for accomplished trade-union officials or local dignitaries? It is hard to know how many MPs retain a non-political professional activity, but surely some activities cannot be practised during the mandate 45 .

[41] These sketchy clues tend to show that it is difficult to argue that the job of a deputy is highly professionalised (for 1983, see Kalaycıoğlu 1988: 60). During the interviews, I sometimes had the impression that some MPs were not very well informed about what was going on in the Parliament, did not know very well the procedures nor the appropriate ways of behaviour (especially MP E). The professionalisation of parliamentary roles is frequently believed to cause significant changes in parliamentarians' behaviour.

[42] Many MPs don't consider themselves to be professionals: 'If you want the truth, I still haven't discovered the subtleties of parliamentarianism'46; 'I used 'politician' in the sense of an occupation, a profession, i.e. somebody who spends all his time, energy, investment, strength, and money in politics, and who therefore wants to stay in politics at any prize, to be re-elected as an MP. I have never been like that' 47 . In this perspective, the subtitle of Kocaoğlu's book (2003), 'Ankara souvenirs of an inexperienced MP', is interesting. All these also show the pejorative connotation of professional politics.

[43] Therefore, there seem to be no strong standardization of role learning, neither through the main ways of transmission of political roles (party and elected offices) nor through the professionalisation of legislative activity. Thus, the learning and socialization process varies from an individual to another. It strongly depends on each MP's social characteristics, trajectories, and conditions of access to the parliament, according to whether they have been active in a party, an

\footnotetext{
${ }^{45}$ Such as civil service. Since 2001, solicitors also have to interrupt practising to enter the Assembly.

46 Interview, MP F, Ankara, 22/04/2005.

47 Interview, MP B, Ankara, 15/04/2005.
} 
Citation: Massicard, Elise (2005) 'Differences in role orientation among Turkish MPs', European Journal of Turkish

Studies, Thematic Issue N³, Being a MP in contemporary Turkey, URL : http://www.ejts.org/document499.html

To quote a passage, use paragraph (§).

associative or trade-union work, or whether their election is due to support outside the political field.

Hence, it is even more important to take in account extra-parliamentary experiences that predispose

MPs to assume the prescribed roles and shape the ways they do.

\section{Main resources shaping role orientation}

[44] MPs differ strongly in the ways they allocate their time and energy to different components of parliamentary work. Some focus on committee work, others on the plenary, some devote much time to prepare thoroughly legislative activities, other do first and foremost casework. There are probably equally large variations in extra-parliamentary activities: national and sub-national party work, pressure group contacts, attending of constituency local life, and media coverage. A large amount of the variation in behaviour of individual MPs cannot be simply accounted for by party, and must be due to other factors, like individual resources and role orientations. What shapes MPs' role orientation?

[45] The only work addressing the question of role differences in Turkey is that of Kalaycıoğlu (1995). He identifies four 'representational styles', mainly according to types of clientelism patterns and interests that MPs represent: the 'landlords', the 'gentlemen of the periphery' (these two groups representing about three fourths of the MPs), the 'lobbyists' and the 'diplomats'. The main factor he selects to explain these differences is the type of constituency represented ('rural constituencies', 'small cities', 'Ankara \& Izmir', and 'Istanbul'). In a way, he follows American political scientists, who have concentrated primarily on the repertoire of representative roles (Wahlke et al. 1962). However, this approach neglects other dimensions of MPs' role-set. I would like to take their role orientation as a whole. However, including many dimensions makes it difficult to construct a typology of coherent roles without conducting further systematic research.

[46] When looking at other factors, it seems important to turn to the individual level. My basic assumption is that MPs' role orientation strongly depends on resources at their disposal. In this perspective, I shall try to present the main resources shaping MPs' role orientation, and the way they do. In my view, three main factors strongly influence the MPs' role orientation: their position within the party, their extra-parliamentary (mainly professional) skills, and their relation with their constituency. 
Citation: Massicard, Elise (2005) 'Differences in role orientation among Turkish MPs', European Journal of Turkish

Studies, Thematic Issue N³, Being a MP in contemporary Turkey, URL : http://www.ejts.org/document499.html

To quote a passage, use paragraph (§).

[47] However, it would be misleading to assume an automatic, causal relationship between initial resources and role orientation. Rather, some resources are given added-value, entertained, reinforced, transformed - for example non-parliamentary resources into political ones - while others are neglected, depending on institutional contexts, perceived opportunities, and individual strategies (Lacam 1988). This process-wise approach implies that the diachronic dimensions and the changes in the course of the legislature have to be taken into account.

\section{Relation to the party}

[48] The MPs' role orientation strongly depends, first of all, on whether their party is in government or in the opposition. In many ways, the role of individual MPs changes dramatically with shifts of governments or party changes, since institutional constraints on them are very different. Differences in role behaviour between majority and opposition MPs have been demonstrated in various studies on other countries, and seem to be relevant for Turkey too (Aslan-Akman 2005). For example, plenary questions are asked almost exclusively by opposition members, in Turkey like in many other countries, as is obvious in our sample. The committee work of opposition members is more demanding, since the government prepares most draft bills, therefore there is no much work left for majority MPs. On the contrary, attendance to the plenary sessions is, on the whole, higher among majority MPs than among opposition MPs, since the vote of the former is necessary to pass the laws ${ }^{48}$. Therefore, party membership is the first factor shaping MPs' role orientation. However, relation to the party also shapes to a large extent one's parliamentary positions.

\section{Positions within the parliamentary institutions}

[49] The main factor of distinction between role orientations within the Assembly is the internal division of labour, especially between 'leaders' and 'backbenchers', i.e. those who hold some formal position of leadership and those who hold none. Here I refer to the distinction introduced by Searing (1994) between 'position roles' and 'preference roles'. Position roles are 'closely tied to, and highly defined by, prominent positions in the institutional structure' and are practically forced upon the incumbents of positions that are very demanding. Having or not a position is important in terms of

48 Interview, MP B, Ankara, 03/11/2004. 
Citation: Massicard, Elise (2005) 'Differences in role orientation among Turkish MPs', European Journal of Turkish Studies, Thematic Issue N³, Being a MP in contemporary Turkey, URL : http://www.ejts.org/document499.html To quote a passage, use paragraph (§).

legislative activities: for example, backbenchers are more active in introducing questions than the parliamentary group leadership. But what interests me here is that the positions within the Assembly are the most crucial casting moulds of legislative roles, since fellow MPs attach quite specific role expectations to them. This is especially true for leadership positions such as chairman or spokesperson of a committee or a parliamentary group. AN MP has to live up to those expectations attached to his position if he intends to be promoted within the hierarchy of his parliamentary group (Patzelt 1997:57). On the contrary, preference roles 'are less defined, and allow more scope for individual preferences to shape role interpretations'. Backbenchers have the opportunity to shape their role orientation to a larger extent than ministers or committee chairs, whose role is quite determined.

[50] This distinction is even inscribed spatially in the buildings of the parliament. Most MPs have their office (makam) in the Public Relations Building (halkla ilişkiler binası), which was opened for service in 198449. However, the main position role holders do not: some of them work mostly outside the Parliament - ministers in their ministries, members of party boards in the party building, etc. In the TBMM itself, a special space is reserved for the position role holders: the offices of the members of the Bureau of the Assembly, of the parliamentary group boards, and committee directors are located in the 'main building' (anabina), which is also the place where the General Assembly Hall is located, where the plenary sessions, committee and parliamentary group meetings take place, and where the media have their offices. This building, which is older than the Public Relations Building - it was opened for service in 1961 - is also much more difficult to access for visitors. It also seems that this building has another rhythm since, as I could observe it,_there are very precise clocks everywhere, which is not the case in the Assembly's other buildings. Its very name (anabina) reflects a strong hierarchy of activities. Thus, there is a kind of spatial specialization between legislative activities and reception of visitors.

[51] Now, how many MPs hold position roles? The Bureau of the Assembly is composed of fifteen members (one President, four Deputy Presidents, seven Secretary Members and three Administrative Members), all elected from among the MPs. Each of the seventeenth specialised permanent committees established to scrutinize bills and control government activities have officers -

${ }^{49}$ Before 1984, MPs received visits outside the Parliament. 
Citation: Massicard, Elise (2005) 'Differences in role orientation among Turkish MPs', European Journal of Turkish Studies, Thematic Issue N³, Being a MP in contemporary Turkey, URL : http://www.ejts.org/document499.html To quote a passage, use paragraph (§).

such as a chairman, vice-chairman, spokesperson, and secretary ${ }^{50}$, totalising about 70 positions ${ }^{51}$. However, in mid-term the committee members and positions are redistributed. Therefore, in one single legislature, more than 70 people can hold these positions. Unfortunately, no precise data about the level of stability of these positions is available. The commission directors we interviewed (MPs I, K) remained stable throughout the legislature. On the other hand, MP E was only a committee member in the first half of the legislature, and was elected as the vice-chairman of another committee in the second half.

[52] Finally, the political parties' hierarchical structures also create positions: most members of the party boards are MPs as well52. But the parliamentary groups also produce specific positions: the chairman of parliamentary group (grup başkanı) is at the same time the leader of the party, therefore it is not really a parliamentary position; his assistants are the deputy chairs (grup başkanvekilleri). Most parties have limited their number to three, however other parties have more (for example, AKP has five); the parliamentary groups' executive committee (grup yönetim kurulu), which comprises nine to eleven members (however, the AKP has up to 15), the group supervisors (grup denetçileri) which are two per party group; finally, the group discipline council (grup disiplin kurulu), which is composed by three to seven people per parliamentary group (Bakırcl 2000: 298307). This amounts to 17 to 23 positions per party group, the AKP having 27 at the end of 2005 .

[53] Therefore, the number of parliamentary positions can be put at an estimated 85 plus about 20 per party group, that is from 125 to 185 positions, i.e. from $22 \%$ to $33 \%$ of the total amount of parliamentary seats, depending on the number of parties with a parliamentary group. We have to consider also the minister offices, which can, but must not, be given to MPs. However, one single MP may hold several positions at the same time, although there are some restrictions: ministers, members of the central executive committee (merkez yönetim kurulu) of a party, and deputy chairs can not seat in permanent committees. It would be interesting to analyse further the people holding

\footnotetext{
50 In addition, the examination of accounts committee has a supervisor.

51 There are also other kind of committees, like international friendship and control committees, but they are more or less voluntary, and not very binding in terms of role.

52 Party leaders, the Prime Minister and most ministers are MPs. In fact, Turkish political parties are mostly headed by parliamentarians, and usually the role of a party leader cannot be separated from that of an MP, even if it is not true the other way round. In 2005, among the 81 members of the CHP board, 52 were MPs, i.e. about $64 \%$. However, those members of the leadership who were not MPs were exclusively members of the party assembly; all higher position holders were MPs. This relation is even clearer at the AKP, where $82 \%$ of the members of the central directing committee are MPs, and all other party leaders are also MPs (figures for the party direction elected in October 2003).
} 
Citation: Massicard, Elise (2005) 'Differences in role orientation among Turkish MPs', European Journal of Turkish Studies, Thematic Issue N³, Being a MP in contemporary Turkey, URL : http://www.ejts.org/document499.html To quote a passage, use paragraph (§).

one or several parliamentary positions, their particular profile, and their chance for re-election. Suffice it to say here that the proportion of MPs with positions seems lower than in many countries, for example Germany, where $15 \%$ of MPs are committee chairpersons $-12.7 \%$ in the TBMM,$- 28 \%$ are members of a parliamentary group's executive committee - about $12 \%$ in the 22nd Turkish Parliament, after ANAP has become a parliamentary group-, and $6 \%$ are members of the presidium of the parliament - only $2.7 \%$ for the TBMM (Patzelt 1997: 57 ). The position of backbencher without any special parliamentary position seems to be found in the Turkish Parliament more often than in Germany.

[54] These positions mould MPs' role constraints. Whereas members of the group leaderships are most active in the plenary, members of important committees are very active in committees: members of committee boards all told me that the plenary sessions were not their priority. For example, MP K, leader of an important committee, declared 'I don't participate too much in the plenary when I don't have a special job to do there'53. However, not all of these positions are equally binding in terms of role-orientation. Their binding character differs in part with formal levels of political leadership, which for a committee office would vary both with the importance ascribed to the committee and with that accorded to the committee leadership position (Frey 1965:242). The committee rankings given by Frey (1965:241-242, 445-447) with the attribution method cannot be extended automatically for the post-1980 period. However, according to all my interlocutors, the paramount committee is the Plan and budget committee, which has a central role in the legislative process since every law having a financial aspect - i.e. nearly every law - goes through it before being discussed in the plenary. Therefore, being a mere member of the plan and budget committee may be more binding in terms of role orientation than being the secretary or even the vicechairperson of the examination of accounts committee. The binding character of committee membership differs in part according to how time-demanding it is. Some committees gather very often, others do not. Again, the plan and budget committee is very time-demanding, while the petition committee seems to have quite light an agenda. Therefore, both leadership positions and committees an MP is member of are important to understand his role constraints. As MP K, chairman of an important committee, puts it: 'For me, it is now a kind of senior period (abilik dönemi). Everybody ask

53 Interview, MP K, Ankara, 21/04/2005. 
Citation: Massicard, Elise (2005) 'Differences in role orientation among Turkish MPs', European Journal of Turkish Studies, Thematic Issue N³, Being a MP in contemporary Turkey, URL : http://www.ejts.org/document499.html To quote a passage, use paragraph (§).

what I think. And when people behave like that, you too, like it or not, you get into this position, it's not possible any more to stand up, go to the pulpit and make a speech causing to stand up'54.

[55] How are these positions distributed? The main instances dividing positions are the parliamentary groups ${ }^{55}$. After entering the TBMM, MPs may express three wishes about committee membership. Then, the parliamentary groups distribute them according to how many seats each they have in each committee (on the basis of the relative strength of the parties in the General Assembly). If they wish, some MPs can get several committee assignments: MP $C$ was a member of three permanent committees at the same time, and even took leadership positions in two of them. The groups need to have members on all committees, and not only on those that are attractive to most MPs. Therefore, they sometimes send MPs to committees where they do not wish to seat (which was the case of MPs B, E for the first mid-term). Formally, it is the group assembly as a whole that decides on committee placements, but the group leadership has crucial functions in this respect, and makes use of that power to distribute reward and punishment. Group leaderships probably assign to the most important and/or attractive committees the MPs they trust the most and they think will do good work. In this respect, the trajectories of both MPs in our sample who had previous parliamentary experience ( $\mathrm{K}$ and $\mathrm{L}$ ) show ascension in terms of the importance of the committee they were members. In contrast, MP B and some other MPs had taken an oppositional stance against his party. He answered to my question about the results: 'the most of us were expelled from the committees'56. In the second mid-term, he was not given any permanent committee membership - since some MPs may have none. On the other hand, after having worked during the first two legislative years in an expert group for the party headquarters, MP L was affected in the second mid-term to the Plan and Budget Committee. The redistribution of committee memberships at mid-term is a kind of readjustment linked to the groups' appreciation of MPs' performance.

[56] As for the committee leadership positions, the party group leaderships agree with each other over their distribution per party (Bakırcı 2000: 304). Then, the committee boards are elected by the committee members. However, especially for important committees and for chair positions, the party leaderships have a decisive, though informal, role. MP K, who has a long experience in the

\footnotetext{
54 Interview, MP K, Ankara, 21/04/2005.

${ }_{55} \mathrm{MPs}$ without a party group (independent MPs or MPs whose party has less than 20 representatives) have no committee membership.

56 Interview, MP B, Ankara, 15/04/2005.
} 
Citation: Massicard, Elise (2005) 'Differences in role orientation among Turkish MPs', European Journal of Turkish Studies, Thematic Issue N³, Being a MP in contemporary Turkey, URL : http://www.ejts.org/document499.html To quote a passage, use paragraph (§).

TBMM, admitted that 'in general, the committee chairpersons are determined by the party board and the party leader'. When I asked him how himself became the committee chairman, he answered: 'I didn't want to, the Prime Minister wanted me to'57. For less important committees and minor positions like secretaries, the groups' pressure may be less important: MP E was elected vice-chairman in a not very important committee during the second term, even if he was not very close to his party leadership.

[57] Therefore, the main institution distributing parliamentary positions are parliamentary groups, themselves being very closely tied to parties. They also organize labour division while assigning responsibilities more restricted in time. The groups decide about which MPs speak in the name of the party on the floor. The deputies also have to take the consent of the group leadership for most of their legislative initiatives, such as the submission of law proposals, motions for questions, or the making of a speech in the plenary sessions, even in their own name ${ }^{58}$, and even to make a speech in the party meetings ${ }^{59}$. Those who violate these rules can be subjected to various sanctions and punishments.

[58] Through these processes, groups have a strong control on legislative behaviour but also, to some extent, are the gatekeepers to role orientation. 'In general, the party gives some duties, they say: "prepare yourself for this law proposal" 60 . MP A, who was very close to the party leadership at times, made several speeches on the floor in the name of the party on important subjects (budget), which were related to his area of expertise, although he was not a 'group spokesperson'. MPs are far from being passive in this process, they can try to get some duties, by showing their will to engage: 'They gave me [these duties] also because I wanted to do some work'61. Parliamentary groups can also to a certain extent orientate given MPs on specific issues: for example, MP C was asked by his party group to cover a quite technical issue he was not familiar with. However, the party also

\footnotetext{
57 Interview, MP K, Ankara, 21/04/2005.

58 In every session, three MPs can make a speech out of the agenda; in the 22nd Assembly, two of them are generally from the AKP, and one of them of CHP.

59 In each weekly party meeting, only three speeches are accepted. The party leadership may also decide that nobody should speak. To get the authorization to give a speech in the group meeting, it is often necessary to give the text of the speech in advance to the group leadership.

60 Interview, MP B, Ankara, 15/04/2005.

61 Interview, MP C, Istanbul, 29/10/2004.
} 
Citation: Massicard, Elise (2005) 'Differences in role orientation among Turkish MPs', European Journal of Turkish Studies, Thematic Issue N³, Being a MP in contemporary Turkey, URL : http://www.ejts.org/document499.html To quote a passage, use paragraph (§).

entrusted him with this duty because he was preparing thoroughly his speeches and was politically reliable: 'I also made some speeches to defend the party against attacks' 62 .

[59] Some MPs feel marginalized by these procedures, for two main reasons: first, because they are not given any responsibility by the group leadership: 'because I was an opponent, they did not make me speak (...) It never happened that I went to a conference or I appeared on television as a spokesperson entrusted by the party'63. In the same way, MP E has never been given any plenary discourse in the name of his first party: "It happens that I participate often to the plenary sessions, but I was not given any duty to do (...) the party does not really test you, and because it doesn't ask you on which issues you have knowledge, what you could be able to do, in which activities you could participate nor what kind of thoughts you could produce on which laws, the deputy chairs choose their own guys (...). There is a core staff which they like and this staff speaks all the time'64. The second reason why some MPs feel marginalized is because the party can block their initiatives. 'I had prepared a law proposal. The party leader and the deputy chairs came, saying 'it's impossible, how can you engage in such an initiative without asking us?' (...) Unfortunately, they hindered me'65. Some MPs would just not take the risk of being blocked - may be because they know better the implicit limits - and would take advice from the party leadership before submitting any initiative.

[60] Which kind of MPs do party leaderships marginalize? They would not give responsibilities to their opponents, those MPs who often don't vote according the party line, and to those whom they are not very confident about. Parties would also not give responsibilities to MPs who are not very close to the party board and have no special skill. By having no legislative responsibility, those MPs enjoy more scope to shape their own role-orientation, but do not have much access to party resources. However, parliamentary groups do not have interest to marginalize or to hinder too much the deputies they don't control, because then there is the risk for party change actually, MP E resigned from his party. Rather, they may try to neutralize or ride along with the MPs they are not confident about (Kalaycıoğlu 1995: 54).

[61] By having no responsibility, backbenchers have difficulties to access the national media, which is believed to be important for their public image. Activities having no legislative effect but

\footnotetext{
62 Interview, MP C, Istanbul, 29/10/2004.

63 Interview, MP B, 03/11/2004 and 15/04/2005.

64 Interview, MP E, Ankara, 24/04/2005.

65 Interview, MP E, Ankara, 24/04/2005.
} 
Citation: Massicard, Elise (2005) 'Differences in role orientation among Turkish MPs', European Journal of Turkish Studies, Thematic Issue N³, Being a MP in contemporary Turkey, URL : http://www.ejts.org/document499.html To quote a passage, use paragraph (§).

which are broadcasted on Meclis TV or elsewhere - like submitting law proposals, asking oral questions, and delivering speeches on the floor in their own name - are ways of demonstrating publicly their legislative activity, which are hardly hindered by parties. Most of them try to publicize these activities even more by communicating them to national media. Some, like MP E, complaint that they are not given sufficient attention. Positions holders, like MP I, the chairman of an important committee, have another relationship to media and to these legislative tools: 'It is necessary that our other colleagues (...) take the floor from time to time and send a message to the voters telling them 'I am here, too'. In order to give them occasions to do that, it is necessary that we don't take the floor too often. Because I appear very often on TV programs, I am in the press every day anyway'66. 'I have never made a speech out of the agenda, because I don't believe that to be very effective. Making a speech out of the agenda is like telling the voters through the TV 'look, I'm here'. I didn't need that, because I am a very busy and appreciated MP (...), my name is well known, anyway (...) I have enough publicity'67.

\section{Relation to the party}

[62] The parties control resources that are essential for a politician's career, like the distribution of power positions and responsibilities in the parliament and in public institutions, and electoral nomination (Nay 2003: 547). In many cases, the position on the party list contributes more to a candidate's election than his popularity or link with a particular segment of the electorate (Hazama 2005: $\S 17,18$ ). Except for very few parties, and in few constituencies 68 , it is the party leadership that selects and ranks the candidates on the ticket, even if local organisations can influence informally the ranking in few cases. Proximity to the party leadership also means more facilities in terms of access to resources, and, in some cases, more demands and more possibilities to build social support: 'because I'm a founding member of the party and people think I have weight in the party, the citizens sometimes come to me saying 'they told me that if you are the intermediary it should work better"69. As a whole, MPs are highly dependent on their parties for re-selection as

\footnotetext{
66 Interview, MP I, Ankara, 21/04/2005.

67 Interview, MP C, Istanbul, 27/04/05.

68 In the 2002 legislative elections, only the DYP organized primaries in 28 provinces, and the CHP in 11 provinces, all the other candidates where designated by the party headquarters (Massicard 2003: 9).

69 Interview, MP I, Ankara, 21/04/2005.
} 
Citation: Massicard, Elise (2005) 'Differences in role orientation among Turkish MPs', European Journal of Turkish Studies, Thematic Issue N³, Being a MP in contemporary Turkey, URL : http://www.ejts.org/document499.html To quote a passage, use paragraph (§).

parliamentary candidates, re-election, access to resources, and career advancement. Therefore parties, serving as the major gatekeepers in a political career, do have strong pressure tools on MPs.

[63] Nevertheless, MPs do not approach party institutions in the same way, since they have different positions in their parties and differing representations about what kind of party backing they need. The few MPs who do not expect to be re-nominated in the coming elections do not feel strong group pressure. But many MPs feel highly dependent on their party's backing. Most MPs who were asked by the party board to become candidates without strong local backing and without being party members whatsoever also feel strongly dependent on the party if they want to be re-elected. These would vote according to the party line, try to demonstrate their loyalty to the leader, to be overzealous by showing intense activity in the service of party interests, and to get responsibilities; more generally, they would try to act according to what they think the party expects from them. Such are for example MPs who have been nominated due to their links with the national organisation. They feel they need the backing of the party to secure a nomination on a party list in the next elections. It is the case of MP D, who lived for more than 30 years abroad and returned to Turkey for the 2002 elections. Even if he had important positions in the country where he had settled, he has no local backing at all and few acquaintances in Turkey: 'I apply party discipline. I won't express any other idea. Well, if there is a very important issue, I speak with the party leader in the group meeting, I tell him what I want to say, I discuss with them which opinion I should give, I ask their advice... In every issue I try to reflect the party's opinion'70. He describes his own position in the party as follows: 'I gain more and more importance'. Since October 2003, he is a member of the CHP party assembly. In the same manner, MP J - who was the last elected on the list in his constituency- has stuck to the party line and taken the responsibility of the leadership of a subcommittee. He also managed to be entrusted to speak in the plenary in the party's name, and finally was nominated as a minister.

[64] Extra-party resources - especially social support - which some MPs enjoy make them somehow less dependent on their party's backing, or give them better arguments to be put on the list. Even if they think they are less dependent on the party, most of these MPs would try not to alienate the leader. Some, though remaining loyal, would pay 'minimal service' to the party. Some MPs do not regularly attend the plenary sessions, come in and out of the plenary sessions while hanging out in the corridors, and enter the meetings only at the moment of the voting, to vote according to their

70 Interview, MP D, Ankara, 02/11/2004. 
Citation: Massicard, Elise (2005) 'Differences in role orientation among Turkish MPs', European Journal of Turkish Studies, Thematic Issue N³, Being a MP in contemporary Turkey, URL : http://www.ejts.org/document499.html To quote a passage, use paragraph (§).

group's line. Aslan-Akman suggests that these MPs are usually the ones who are not very familiar with the legislative process, those MPs who devote more time and energy to constituency work (Aslan-Akman 2005: 44).

[65] MP E - the last elected on the list - seems to have tried, at the beginning of the legislature, to get a higher place into the party and to build good relations with the leadership. The party leader was the witness of his wedding, which took place during his mandate. However, he voted against the party line when he disagreed on some issues related to his constituency, and was impeded by the party from doing some proposals and discourses. He joined the internal opposition during a party congress, and discipline proceedings were being taken against him when he finally resigned from his party. This MP, who had no special parliamentary or party responsibility but was elected mainly because of strong personal backing, followed opinions expressed by his constituents when they diverged from the party line, privileging social support over his party backing. Afterwards, he joined another party that he may have considered had better chances to enter parliament in the next elections than his previous party.

\section{Professional resources}

[66] Non-political, especially professional, resources influence MPs' role orientation. Political parties play an active role in the selection of political personnel. Party boards know that they need MPs with different types of competence. They need for example some MPs able to serve on parliamentary committees in the European legislative bodies in which Turkey is represented (Kalaycıoğlu 1995: 54). Parties also nominate candidates who are specialists of some issues, because they plan to take benefit from their expertise. The main non-political or professional skills that seem important in the shaping of MPs' role orientation are: technical knowledge (especially juridical), oratory skills, relational resources, and fame ${ }^{71}$.

[67] Many of the MPs without political experience, and who are invited by the parties to run as candidates, are people having professional resources, which can be reinvested in parliamentary

71 We have to distinguish parliamentary skills from political skills. Whereas oratory skills may be enacted in parliamentary but also other political activities (campaigning), juridical knowledge is best employed in the legislative process and may not have many other uses in the political field. 
Citation: Massicard, Elise (2005) 'Differences in role orientation among Turkish MPs', European Journal of Turkish Studies, Thematic Issue N³, Being a MP in contemporary Turkey, URL : http://www.ejts.org/document499.html To quote a passage, use paragraph (§).

work. This is the case of MPs B, $\mathrm{F}^{72}$ and $\mathrm{H}$ in our sample: they came from the academy, law, and bureaucracy. This kind of MPs does not necessarily need strong grassroots support. This is turn affects his role orientation. However, parties prefer professional skills only if they are used in their interest and do not always permit much independence from party organisations. Some of these MPs $(F, H)$ - probably those who want to stay in politics - are loyal to their party, act mainly as technicians, accepting or even legitimising party control and party discipline. Others (MP B) behave in a more independent way, since they have alternative career prospects.

[68] As a matter of fact, people having important professional skills also have a previous career on which their entry into politics depends. MP F was retired when he became MP; MP B had been asked to run in the 1995 elections, but he refused as he had other career prospects; in 1999, since his career prospects had vanished, he accepted. Only two MPs in our sample (B and E) retained an extra-parliamentary occupation during their mandate, with interests related to it. But even previous professional experiences shape MPs' worldview, values, and interests. For example, those who have been active in NGOs are more likely to be policy-oriented, as is obvious in MP C's use of legislative tools: 'There are speeches in the party's name and speeches in one's own name. Speeches in one's own name have no effect. It's only to say 'I have spoken, too'. Speeches in the party's name have effect. I gave speeches in the party's name only'73. Of course, this is also because MP C did not need grassroots support and was close to the party board. Finally, professional experience shapes their future prospects. Their professional career often permits them to project their future somewhere else than in politics, and makes them less dependent on parties: 'I never said 'I absolutely want to be an MP again, at any prize"74. All previous MPs interviewed for this study (A, B, and $\mathrm{C}$ ) returned to their occupation after their mandate. Civil servants and professionals can turn back to their job quite easily.

\section{Technical know-how}

[69] The first important skill that can be turned into a parliamentary resource is technical knowledge. Each group has specific MPs competent on specific issues, who often take the floor on

\footnotetext{
72 MP F became a member of CHP in 1999, because he was asked by the party direction to run as a candidate for the legislative election, which was again the case in 2002.

73 Interview, MP C, Istanbul, 29/10/2004.

74 Interview, MP B, Ankara, 03/11/2004.
} 
Citation: Massicard, Elise (2005) 'Differences in role orientation among Turkish MPs', European Journal of Turkish Studies, Thematic Issue N³, Being a MP in contemporary Turkey, URL : http://www.ejts.org/document499.html To quote a passage, use paragraph (§).

behalf of their party group 'TThe party group] gave me the floor on issues I was familiar with (...) Because I was an expert on this issue, it was necessary that I made the speech'75. 'In general, I speak very rarely on the floor. But in some periods and on certain issues requiring proficiency, I speak as an arbitrator'76. The committees are another place where technical know-how can be easily valorised. Since work occurs in small groups, knowing the issues here is much more important than on the floor where voting is often sufficient. MPs tend to get committee assignments corresponding to the policy area with which they are familiar, thanks to their previous education or experience. Most frequently, MPs explained the reasons of their committee membership by their skills in the policy area in question, and sometimes by a general interest.

[70] MP H is a case in point. Before being elected, he had worked during more than twenty years as an attorney, specializing in public and administrative law. He became a member of CHP only a few months before the elections. His juridical know-how can be especially useful for control activities, since he is in the opposition. During the interview, he stressed the continuity between his former profession and his activity as an MP: 'I had an advantage from a professional point of view (...) You know the mechanism from before, anyway'. He concentrates on things he can influence upon as a jurist, i.e. not on political issues, but on irregular proceedings (like corruption or spoils) and parliamentary immunity. He has rapidly focused on written questions, which he finds more effective in terms of results than oral questions, law proposals or investigations. During the first three years of the legislature, he has asked almost 300 written questions. He is the only MP to have answered to my question about time allocation that he spends much time in his office, preparing the files and following up the cases. His skills can also be employed in committee work. At the beginning of the legislature, he had wished - and has obtained - a juridical committee. He attends every single committee meeting, and is very active there, too ${ }^{77}$.

[71] Another skill that is often reinvested in parliamentary work is knowledge of bureaucracy. Many former bureaucrats become MPs. MP F was a high civil servant specialized in public finance. He also stresses how useful his previous professional skills are for his MP activity: 'I often came to the Assembly as a bureaucrat (...) with the ministers, when laws were changed (...). It proved to be useful, the fact that I knew on what level the discussions take place and how made it easier for me as

75 Interview, MP C, Istanbul, 29/10/2004.

76 Interview, MP I, Ankara, 21/04/2005.

77 Interview, MP H, Ankara, 21/04/2005. 
Citation: Massicard, Elise (2005) 'Differences in role orientation among Turkish MPs', European Journal of Turkish Studies, Thematic Issue N³, Being a MP in contemporary Turkey, URL : http://www.ejts.org/document499.html To quote a passage, use paragraph (§).

a new politician'. This knowledge was probably decisive in his assignment to the plan and budget committee: 'As a person knowing how the governmental machine works, I expressed the wish to be assigned to the Plan and Budget Committee. (...) Of course, this work gives you some knowledge, and I thought that the place where this knowledge can be efficiently used is the Plan and Budget Committee. Because in the plenary, when you know about something, you can't speak. In the plenary, other MPs speak more often, but there is a technical dimension in my work. I consider myself, more than as a politician, as a technician (...) In the plenary, when I am appointed as a member of the Plan and Budget Committee, I get the chance of transferring my knowledge from there ${ }^{178}$. He is sometimes mandated to speak in the name of his party on the issues he is specialized in, but does not engage much in discourses in his own name. He is also very active in written questions, since he has asked about 170 during the three legislative years.

\section{Oratory skills}

[72] Both the floor and the committees are places where the individual MPs' oratory skills can be demonstrated and reinvested. The ability to make impressive discourses makes an MP more likely to be chosen as a spokesperson: 'Sometimes, the group deputy chairs want certain persons to speak on certain articles of law (...) because they believe their speech will be more influential, more striking'79. By reinvesting and enhancing this skill, some MPs can achieve to be entrusted more duties: "I took the speeches in the Assembly very seriously (...). On important issues, they generally sent me in the party's name (...) Because I was always well prepared when I took the floor, I was considered to be a good speaker in the Assembly. Then, [the party group] entrusted me also with issues I was not familiar with'80. These skills also make their holders more confident to take the floor. Most of the MPs interviewed who considered they had these skills were academics, lawyers and militants (MPs B, C, G, I). Available evidence suggests that the most frequent and ardent speakers in the CHP group have law or academic backgrounds (Aslan-Akman 2005: §35). This skills shape roleorientation, since they provide for those MPs more visibility, make public figures out of them, and give them access to media.

\footnotetext{
78 Interview, MP F, Ankara, 22/04/2005.

79 Interview, MP F, Ankara, 22/04/2005.

80 Interview, MP C, Istanbul, 29/10/2004.
} 
Citation: Massicard, Elise (2005) 'Differences in role orientation among Turkish MPs', European Journal of Turkish Studies, Thematic Issue N³, Being a MP in contemporary Turkey, URL : http://www.ejts.org/document499.html To quote a passage, use paragraph (§).

\section{Fame}

[73] Some people have been nominated candidates mainly because of their fame, for their contribution to the party's public image, notably during the campaigns - this is the case of some artists, writers, or singers (Günay 2005). But how does fame shape their role-orientation as MPs? Fame shapes public expectations towards MPs and can increase the demands they are subjected to, since people would first go to them. The scope of their fame therefore orientates the audiences with whom they are in contact with: 'The fact that I am well known in my constituency, well, the circle of my relatives is very broad... Besides their demands, I got very numerous demands from other voters in my constituency'81. 'Because I was the general accountant of the party, the whole organisation called me. Every accountant of a subprovincial organisation, every provincial party leader knew me. Besides, people from my region have spread over Istanbul and Ankara, voters from Istanbul came to me, too, and they connected to relatives or people who knew me. All of them carried their problems to me'82. 'Because I was in the university before, I have a great amount of students. Their children and grandchildren have grown up now. And many people know me from the television, from other places. They are neither from [my place of birth] nor from [my constituency] (...). Here, I speak everyday to 100 or 150 people in average'83. Therefore, the scope of fame can lead MPs to be more or less constituency-oriented.

[74] However, fame can also provide MPs with more ability to get positive answers to the demands: 'Any bureaucrat whom I call in Turkey (...), well, 99\% of them know my name. While he doesn't know other MPs, he certainly knows me; in the private sector my name is well known, too (...). For this reason, as far as possible, they won't reject my demands. When an MP calls, most of the time they don't want to appear, they are busy somewhere else... but when I call, they certainly answer, well, they don't run away from me'84.

\footnotetext{
81 Interview, MP A, Ankara, 02/11/2004.

82 Interview, MP A, Ankara, 18/04/2005.

83 Interview, MP I, Ankara, 21/04/2005.

84 Interview, MP I, Ankara, 21/04/2005.
} 
Citation: Massicard, Elise (2005) 'Differences in role orientation among Turkish MPs', European Journal of Turkish Studies, Thematic Issue N³, Being a MP in contemporary Turkey, URL : http://www.ejts.org/document499.html To quote a passage, use paragraph (§).

\section{Social capital}

[75] Social relations can also be invested as a resource in parliamentary work. 'I had some relations from the bureaucracy, after becoming MP an important part of these relations continued'85. MP F chose as an assistant somebody he knew from his experience as a bureaucrat, and who, as a member of the Prime Minister high supervision council, has access to much informations. Relational resources can be prioritised for getting information. They are, therefore, important for committee work; they can also be very much valorised in casework. MP I states that: 'From time to time I could come to a result about employment by calling people in the private sector. I have such a circle in the private sector, acquaintances'86. Because of his former relations, he can get more positive answers to demands, and thus, possibly, gets more of them, and gets quite service-oriented ${ }^{87}$.

[76] There is a specialisation process inside the parliament, which is related to the skills of MPs and the way they are valued. Some professional qualifications are not very much valued in parliamentary work (engineering, medicine, industry, commerce). Even if these competences are not applied in the parliamentary work, they can influence the role orientation of individual MPs. Some MPs active in the economic sector may for example act for the defence of private interests, also because the demands addressed to them would be more in that sense. MP M, who was the secretary general of the chamber of industry and commerce of his constituency during 7 years, has many contacts and demands from economic collective actors in his constituency and worked as an economic advisor of his party.

[77] In some cases, MPs cannot get their professional or extra-parliamentary skills recognised and valorised in parliamentary work. It is the case of many MPs who are given no responsibility in relation to their competences and who are assigned to committees where they have neither special skill nor special interest (MPs B, E), which makes it difficult for them to get anything valorised: 'I can't say that I have been very useful to the Petition Committee'88. MP B's opposition to his party was considered more important than his oratory skills, since the party did not entrust him

\footnotetext{
85 Interview, MP F, Ankara, 22/04/2005.

86 Interview, MP I, Ankara, 21/04/2005.

${ }^{87}$ Kalaycıoğlu argues that newcomer MPs have great difficulties in establishing relationships with the public bureaucracy and, hence, experience difficulty in providing benefits in exchange for votes (1995: 50).

88 Interview, MP E, Ankara, 24/04/2005.
} 
Citation: Massicard, Elise (2005) 'Differences in role orientation among Turkish MPs', European Journal of Turkish Studies, Thematic Issue N³, Being a MP in contemporary Turkey, URL : http://www.ejts.org/document499.html To quote a passage, use paragraph (§).

with speaking in the plenary. Therefore, it is only under certain conditions - the first one being loyalty to the party - that skills can be transformed into parliamentary resources.

[78] These skills can be transformed into parliamentary and/or political resources during the mandate. Some of them may help to build good relations with parties, and MPs can achieve to appear as providing skills important for the parties. An example would be MP F. He has managed to be assigned to the Planning and Budget Committee in the second mid-term, although he was not a professional politician and had become a member of CHP quite recently. Both his expertise and his relations in the state apparatus have been valuable to committee work and appreciated by the party even more so since he has stuck to the party line; they have been rewarded as such. Other skills can be transformed in a way to enhance social backing. Here, MP H is a case in point. The media are interested in getting and broadcasting information he collects while following cases of irregular proceedings: 'You share that with your constituency, with national media, and in the end the people make the difference between those who work, those who provide service, and those who don't work. That creates a confidence in the public opinion, and the information flow begins. Information flows to me from [my constituency] and from everywhere in Turkey: from the press, the NGOs, the mere citizens. This constitutes a very serious source for me. By using and cross-examining these informations, you become the contact person (...) My relations with the media are dense, and most of the time, positive'89. In this way, he reinforces his information sources, and therefore his resources to pursue such proceedings. By working with the media, he does not only build good relations with them, but also increases his fame and his public image as a defender against arbitrariness, which is an important political resource. While he had not been given any special power position at the beginning of the legislature, he begins to be well known and recognized in the general public, while working for his party.

\section{Social support}

[79] The last main resource an MP can lean on is grassroots support. How and how far does social backing influence the MPs' role-orientation? Social support can impact on different parliamentary activities: it can influence legislative activities (discourses, motions of question, and law

89 Interview, MP H, Ankara, 21/04/2005. 
Citation: Massicard, Elise (2005) 'Differences in role orientation among Turkish MPs', European Journal of Turkish Studies, Thematic Issue N³, Being a MP in contemporary Turkey, URL : http://www.ejts.org/document499.html To quote a passage, use paragraph (§).

proposals), which can address specific problems of the constituency or some social groups' interests. Social support can also have an effect on MPs' casework politics and constituency service ${ }^{90}$, since an MP may feel obliged to reward or act as the representative of the people who helped for his election, be they constituents or not. Lastly, social support can influence the relation to the party. If the support is attached to an individual and not to any particular party, it makes the MPs less dependent on the party on which ticket they have been elected. In general, these MPs are hardly given power positions in parliament because they are less controllable, and they end up in preference roles - MP E is a case in point.

[80] However, it seems that social backing has only an indirect influence on MPs' role orientation, depending on MPs' other resources and positions. More than the social backing MPs enjoy or not, what seems important in terms of role orientation is, rather, if they choose to reinforce it. Though good relations with the party is a resource few MPs are not dependent of - only those who think they can be elected without the support of a party -, MPs' investment in social support seem much more differentiated.

\section{Changing valuations of social backing: institutional rules and parties}

[81] On the whole, the value of social backing as a resource has been undermined in the last decades. This is due to the changes introduced in institutional rules: first the 10\% threshold, which makes the relation between social support and election a quite haphazard one; second, the candidate selection procedures. The declining use of primaries has put in the background support from the local party organisation and from the constituency. It is possible that the increased importance given to local support before 1980 (before the introduction of the $10 \%$ threshold and when party primaries where much more common) influenced the way MPs behaved towards their constituency - in terms of debt, reward, and investment - and their role orientation. Since our sample includes only one MP $(A)$ who was elected through both party primaries and the preference system ${ }^{91}$, it is difficult to isolate the effects of these institutional rules on role orientation from other factors ${ }^{92}$.

${ }^{90}$ More than half of the deputies Kalaycıoğlu surveyed in 1984 and 1988 reported that they spent the majority of their time on case work.

91 In the 1991 legislative elections, it was possible for the voters to register a voice for a specific candidate, who by getting an endorsement from a minimum of $15 \%$ of the voters could be moved up to the top of the list (Kalaycıoğlu 1995: 46). In 
Citation: Massicard, Elise (2005) 'Differences in role orientation among Turkish MPs', European Journal of Turkish Studies, Thematic Issue N³, Being a MP in contemporary Turkey, URL : http://www.ejts.org/document499.html To quote a passage, use paragraph (§).

[82] Indeed, MP A enjoyed very strong local support both from the party organisation and from constituents. After the primaries, he was the leading candidate on the list; the preference voting confirmed his place, since he gathered more than 19,000 votes (i.e. more than one third of the votes for the SHP). During the campaigns, he enjoyed much support from relatives and supporters. During his mandate, he cared very much about maintaining this social support. First, he kept a strong connection with the local party organization: 'When I was an MP, the candidates I supported always won the elections'93. Second, he went often to his constituency and participated to private ceremonies there. Besides spending one or two months each summer there, 'during the legislative year, I couldn't go as often as I'd wished to, but as far as possible I went there twice or three times a month (...). I spared some time to go to [my constituency], I went around in the villages, I made a program district by district, I made district meetings (...) I went to one or two villages (...), I informed two weeks in advance about my coming (...), those who wanted could come there (...) we discussed and debated with them'94. He made discourses, including on the floor, related to his own constituency. 'I brought much better services to [my constituency] (...), this was much recognized by the people, I followed up the issues as an MP, the demands for roads, drinkable water supply, schools, dam constructions (...) I tried to bring many services, I had caught a very good position in [my constituency] ${ }^{195}$. In fact, an impressive number of plaques offered by his constituents and local hemşehri organisations to thank him are hanged on his home's wall ${ }^{96}$. What enabled him to bring services to his constituency was is positions in the party board, and as a minister for some time. MP A didn't candidate at the next elections, because the system of primaries had been abandoned, and he had fallen in the internal opposition of the party. May be he thought he would not get a good place on the list and would not be elected. Therefore, he is a good example of an MP elected with strong social support in conditions encouraging it, and caring about this resource, which heavily shaped his role-orientation. Now, the designation of candidates by the headquarters often puts local support to the background. As MP C, interestingly enough from the same constituency puts it: 'The MPs are gauged and chosen by the headquarters. You can have as good relations as you want with the local

that legislature, Hazama found that parliamentarians spend for constituency service the largest part of the time at their own disposal (Hazama 2005: §13).

${ }_{92}$ For MP C, the designation process was a mixture: first, candidates entering the election were designated by primaries; then, the party headquarters decided about their ranking on the list.

${ }_{93}$ Interview, MP A, Ankara, 02/11/2004.

94 Interview, MP A, Ankara, 02/11/2004.

${ }_{95}$ Interview, MP A, Ankara, 02/11/2004.

96 Observation, MP A's home, 18/04/05. 
Citation: Massicard, Elise (2005) 'Differences in role orientation among Turkish MPs', European Journal of Turkish Studies, Thematic Issue N³, Being a MP in contemporary Turkey, URL : http://www.ejts.org/document499.html To quote a passage, use paragraph (§).

apparatus, there is no point in it! There is no point in investing in local politics nor in the local apparatus, nobody expect such a thing from you'97.

[83] Not only election rules, but parties also value differently the MPs' social backing. Some parties encourage their deputies - or some of them - to engage heavily in constituency work in order to foster their relations with the masses, or to answer to personal demands in order to get more votes (Kocaoğlu 2003: 27). In some cases, constituency work is considered as party work, as MP M puts it: 'What I consider most important is... committee work and work in my constituency. Party work... in any case work constituency and committee work are all things that the party wants' 98 . MP J, also from the AKP, confirms that: his party organizes the relations between him and his constituents. The local organisation organizes visits to private houses, breakfasts, and meeting with the citizens; it also transmits the citizens' demands and problems to him ${ }^{99}$.

[84] However, others parties give much less importance to social backing. DSP seems to be a case in point, as a former MP puts it: 'The DSP has such a special feature. It does not hold together the MPs and the organisation (...) They didn't want organic relations between the MPs and the organisation (...) Whatever his region, besides being interested in the problems of his constituency, the main duty, the main responsibility of the MP is parliamentary activities (...) Because we had no delegate system, because there were no power relations with the local organisation, it was not necessary to create warm or close ties with the constituency or the organisation there, or to pay much attention to them (...). That relieved us. First, from the pressure of the local organisation. And it protected us from the demands and wishes of the voters. Giving priority to parliamentary work was a right understanding of Ecevit. That's why it was also our priority'100. In another interview, he argues: 'That's why I didn't construct very close or very warm relations with the local organisation... as they could not exert much pressure on me'101. He elaborates on the consequences: 'for example, I did not visit the neighbourhoods or the cities every time I went to my constituency. Anyway, the party did not expect that from us (...) They perceived that as being dangerous, as an attempt to reinforce one's

\footnotetext{
97 Interview, MP B, Ankara, 15/04/2005.

98 Interview, MP M, Ankara, 25/04/2005.

99 Interview, MP J, Ankara, 25/04/05.

100 Interview, MP B, Ankara, 15/04/2005.

101 Interview, MP B, Ankara, 03/11/2004.
} 
Citation: Massicard, Elise (2005) 'Differences in role orientation among Turkish MPs', European Journal of Turkish Studies, Thematic Issue N³, Being a MP in contemporary Turkey, URL : http://www.ejts.org/document499.html To quote a passage, use paragraph (§).

local power'102. In that case, doing constituency service is opposed to answering the party's expectations.

[85] As a consequence, he went not very often to his constituency: 'During the first year, I was going once a month or once in two months. The second year, it became few and far between, in the third year I didn't go much, I went only four or five times. This was criticized a bit (...), the people want to see you'103. His legislative activities were not oriented towards getting more local backing. None of the law proposals he submitted dealt with constituency issues. His speeches dealt exclusively with universalistic topics: 'In the group meetings (...), most MPs argued 'in my constituency they need drinkable water, they need a road, there is a need for agricultural subventions', things like that, but I was the only one making speeches about general political issues'104. As a consequence, 'I can't say that I have got a hospital built here and a school there'105. He used legislative tools accordingly: 'Oral questions (...) are more greetings to the voter. Because TRT-3 broadcasts the whole plenary sessions, the more you appear on the pulpit, the better it is, what you say has no importance. I don't have such trouble'106 Other factors may explain his role orientation, like the fact that he was nominated mainly because of his close relation to the party leader or his 'value-orientation' in part due to his professional background, and his social ascension which was also a kind of departure from his constituency: 'However much I may be from there, I am a stranger to the people from my constituency (...). Some colleagues (...) have organic links to their constituency because they live there. I am from there, but I live in Ankara since 40 years. I have no direct organic link, even if I have relatives there'107. Suffice it to say here that the very relevance of investing in social support can differ according to the party priorities. It would be interesting to further research on what different parties expect from their MPs in terms of relation to social support.

\footnotetext{
102 Interview, MP B, Ankara, 15/04/2005.

103 Interview, MP B, Ankara, 03/11/2004.

104 Interview, MP B, Ankara, 03/11/2004.

105 Interview, MP B, Ankara, 15/04/2005.

106 Interview, MP B, Ankara, 03/11/2004.

107 Interview, MP B, Ankara, 15/04/2005.
} 
Citation: Massicard, Elise (2005) 'Differences in role orientation among Turkish MPs', European Journal of Turkish Studies, Thematic Issue N³, Being a MP in contemporary Turkey, URL : http://www.ejts.org/document499.html To quote a passage, use paragraph (§).

The perceived need for social support: the presence of other resources

[86] In these conditions, how does social support influence role-orientation? Local backing makes it easier to be put on electoral lists by a party. Even if electoral lists are formed by the party headquarters, some MPs perceive a need for local backing to reinforce both their chance for nomination by the party on a high place on the list and for re-election, or because they have other interests in the constituency. According to MP H, the CHP has conducted an opinion poll in his constituency before deciding about the candidates' ranking ${ }^{108}$.

[87] Do all MPs who have been elected with strong social backing adopt a constituencyorientation and try to reinforce their support? It seems to depend on their other resources at hand. Social support is a resource which they can valorise, and sometimes need to, when they have no other. MP E is a case in point. In his constituency, both the AKP and the CHP had much less support than the national average. He was the last elected on his list; he actually got a seat because the threshold resulted in the overrepresentation of the party he ran for, CHP. Therefore, his position is not secure. Even more so since, after having sought to get a better place in $\mathrm{CHP}$, he has turned to the party's internal opposition and finally changed party. In his constituency, he enjoys quite a strong local backing, and says to have gathered individual, and not ideological or party vote - a view that is shared by most observers. However, his grassroots support is not enough to be elected as an independent. During his mandate, he tries to invest in social support. MP E cannot afford to reject the demands of his constituents, even less so because he has no special skill that he could turn into a parliamentary resource. When asked about his priority in parliament, he declares spending most of his time for ill people and constituents. He declares proudly being one of the MPs receiving most visits, and accepting them: 'my door is open'. Even when a plenary session is about to begin, 'my priority is the citizen'109. The great majority of motions of written questions he proposed deals with his constituency. He goes quite often to his constituency, at least twice a month; there, he enjoys strong local go-betweens, and participates to private ceremonies.

[88] Many MPs elected with social support try to maintain it; but they do not all give priority to this dimension, depending on their other resources. MP H has strong ties to his constituency; he was born and has been living there. As a lawyer there, and a person very engaged in NGOs, he enjoys a

108 Interview, MP H, Ankara, 21/04/05.

109 Interview, MP E, Ankara, 24/04/2005. 
Citation: Massicard, Elise (2005) 'Differences in role orientation among Turkish MPs', European Journal of Turkish Studies, Thematic Issue N³, Being a MP in contemporary Turkey, URL : http://www.ejts.org/document499.html To quote a passage, use paragraph (§).

high social standing. In Parliament, drawing on his skills, he is about to construct fame on his own on general issues; however, he has no special position in his party, which he entered it just before the elections, and was the last elected on the list. As an MP, he keeps maintaining social support: about $40 \%$ of his legislative activities address constituency issues. He goes there every week, since his family leaves there. He is not very active in responding to individual demands from constituents, but takes care of his links with local interest groups. In a slightly different manner, MP L from the majority, who was elected with social support, balances between loyalty to the party and representing their constituency's interest. As he puts it: 'When I make speeches about my constituency and there are deficiencies, I do opposition. I criticize and I expect a solution'110. However, he has never voted against the party line, which means that he would not endanger his relation to the party to enhance his constituency backing.

[89] For some MPs elected with social support, this has less importance. It is the case of MP K, who has been elected six times MP since 1977; at that time, he had been designated by primaries, which was not the case any more after 1980. In 2002, he was the leading candidate in his constituency. He has been deputy chair of a party group in the 1980s and is the chair of an important committee in the current legislature. He argues that his priority in the Parliament is committee work. It seems that his high positions make him not very constituency-oriented. None of his legislative activities is linked with his constituency. Still, he goes quite often there and receives many visitors and demands from there. Therefore, the very fact of having been elected with social support does not directly link to a strong constituency-orientation. Rather, the effects of social backing depend on other resources at hand.

[90] How about the MPs elected without strong social backing? It is interesting to note that those MPs (in our sample, MPs B, C, D, F, I, J) hardly adopt a strong constituency-orientation, but rather concentrate on reinforcing other resources. For example, MP F was elected without local backing. He was not born in Istanbul, and has lived there during twelve years only; he left Istanbul twenty years before being elected as its representative. The reason for his being elected from Istanbul is probably mere intra-party electoral strategy. He receives few demands from his constituents. The great majority of his legislative activities (numerous motions of written questions, law proposals) are not related to his constituency. Actually, the reason why the party has nominated

110 Interview, MP L, Ankara, 25/04/05. 
Citation: Massicard, Elise (2005) 'Differences in role orientation among Turkish MPs', European Journal of Turkish Studies, Thematic Issue N³, Being a MP in contemporary Turkey, URL : http://www.ejts.org/document499.html To quote a passage, use paragraph (§).

(at a good ranking) is not in order to be a representative of any constituency. His high position in the centre (both in the party leadership and as a member of the plan and budget committee) leads him not to feel the need to enhance any social backing. MP F is not an exception in this respect. 'I haven't made many question motions. These are greetings to the voters anyway. You ask to the minister of public works why the fountain in your village has not been finished, and then you go to your village and say that you've asked that. But I didn't need those things, I don't need the voters'111. When going to his constituency, the party organized his agenda, and he had contacts with the citizens through the party organization. It seems that social support is a resource that is invested by MPs as a secondary choice or as a complement to other resources. Our hypothesis is that social support is an insecure resource, and enhancing it may appear more time and energy-consuming than, say, loyalty to the party.

\section{Ability and forms of enhancing social support}

[91] Lastly, even if they wish to, all MPs do not always have the means to enhance social support, especially as far as constituency service and casework are concerned. The ability and forms of reinforcing social support highly depend on the position of the MPs. It is easier to build social support through constituency service for majority MPs, or generally for those who have access to consistent resources. For MP K, who has been both in the opposition and in the majority during his long MP career: 'when you are in the majority, you can do many things, you have many possibilities, from the hizmet point of view'112. Even for majority MPs, it is not always easy: 'I had no chance of constructing a hospital in my constituency (...), of appointing doctors, or of opening a factory there: only a great MP has some chance to doing such things'113.

[92] Expectations toward deputies differ consequently according to the type of constituency. Hazama (2005) found that the smaller the constituency size, the larger will be the demand for and the supply of constituency service. All MPs interviewed for this study said that MPs representing rural constituencies were more easily identifiable, had more personal relations to their constituents and personal demands from them. All of them also stated that MPs representing big cities got less social

\footnotetext{
111 Interview, MP C, Istanbul, 27/04/05.

112 Interview, MP K, Ankara, 21/04/2005.

113 Interview, MP B, Ankara, 03/11/2004.
} 
Citation: Massicard, Elise (2005) 'Differences in role orientation among Turkish MPs', European Journal of Turkish Studies, Thematic Issue N³, Being a MP in contemporary Turkey, URL : http://www.ejts.org/document499.html To quote a passage, use paragraph (§).

demands from their constituents, since they were more numerous and had much less direct relations with their constituents. But even if the number and nature of demands is correlated to the type of constituency, it does not determine role-orientation, i.e. how MPs manage and deal with these demands. Some MPs from rural constituencies are very reluctant toward visits and demands (MP B), whereas some MPs from big cities give them a good reception (MP I).

[93] Still, the ability and forms of building social support do depend on the type of constituency. For an MP, answering to the requests from his constituents, appearing as a guest at meetings, special events, openings and so on at the local level, which provide excellent opportunities to make visible public appearance, is easier and more efficient in a small constituency. We should recall that in the 2002 elections, the number of votes necessary to get an MP seat in Istanbul was 143,124, and only 46,792 in Tunceli (Massicard 2003: 2). It is also easier to appear in local media in relatively small constituencies. On the contrary, MPs from big cities are faced with less direct representative duties. But the downside is that these MPs have a much harder time than their colleagues from smaller constituencies to get their names and pictures into the newspapers on a regular basis or to answer the demands in a way that can bring sizeable social support. In a constituency like Istanbul, it is very difficult to build a local base. Therefore, it appears more efficient a strategy to build grassroots support in a small constituency.

[94] Does it mean that an MP elected without social support in a big city cannot built any? It seems necessary to distinguish different types of social support. MP D is a case in point. He has made a political career mainly in Europe, where he had lived since more than 30 years, so he has neither local backing, nor much links to his constituency, Istanbul, where he has never lived. Besides, he is in the opposition; therefore he receives few individual demands. However, it does not mean that he is not oriented toward social support at all, but he tries to enhance one kind of it. He is well known as an activist abroad for a political cause. Since he is back in Turkey, he also acts as an intermediary between the NGOs in this field and his party. He gets demands, and is in contact to, mainly those NGOs, who often turn to him. He also brings this issue into the Parliament through numerous discourses. The CHP confirms his role by entrusting him with discourses on this topic. Thus, he tends to adopt an issue-oriented role. Therefore, it seems that MPs having no strong local backing are more involved in cooperating with organized or collective interests, rather than dealing with constituency relations and rendering personal services. MP C for example answers to the question 
Citation: Massicard, Elise (2005) 'Differences in role orientation among Turkish MPs', European Journal of Turkish Studies, Thematic Issue N³, Being a MP in contemporary Turkey, URL : http://www.ejts.org/document499.html To quote a passage, use paragraph (§).

about his activities when he goes to his constituency, Istanbul, that he attends congresses, political meetings, and meetings organized by NGOs or by labour unions ${ }^{114}$. In the same manner, MP F gets few individual demands, since he is in the opposition, his constituency is Istanbul and he has no social backing there. But the fact that he is member of the Plan and Budget Committee brings him many visits of organized interests, since some committee decides on the allocation of many resources. Answering to the question if he got visitors came because he was a member of this committee, he said: 'they represent the majority [of the visits I get] in fact. As a member of the Plan and Budget Committee, when a law is being discussed, the parties certainly come to me, or sometimes some NGOs linked to them. (...) They bring their own problems and want that their views be defended during the discussion of the bill'115. Other MPs who are members of important committees receive many visits related to their legislative activities, that represent collective interests (MPs I, K, L); therefore, proximity to the party may open the way to a role of mediation of collective interests. Finally, MPs who were elected with social support from local NGOs - like professional chambers - (MPs G, H, L, M) also maintain contacts with these local organized interests during their mandates. MP G, a long-time party member and local leader who made a career in professional organizations and NGOs, receives few individual demands, and does not take much care of them. In his constituency, he has contacts first and foremost with party organisations, local authorities, and NGOs. In contrast, he does not privilege participating in private ceremonies. In general, it appears handier to maintain types of social support with which one has been elected, than to build new ones.

[95] In that sense, it seems important to make a difference between social support from individuals and attached to the person (as is the case for MP E). It seems that answering to individual demands from constituents and acting as an intermediary with collective and organized interests (be they local or more policy-oriented) are very different in terms of role-orientation, and are perceived as such by MPs: 'I interrupted the opportunist visits. I made them understand that I could nothing for them and they saw that I did not handle their cases. But there were also people coming to me for general issues like democratisation or human rights. For example, when there were privatisations, but not for nominations in a position. In that case, I tried to help them'116. MPs elected without personal social backing seemt to be more likely to end up mediating with organized and collective

114 Interview, MP C, Istanbul, 29/10/2004.

115 Interview, MP F, Ankara, 22/04/2005.

116 Interview, MP C, Istanbul, 27/04/2005. 
Citation: Massicard, Elise (2005) 'Differences in role orientation among Turkish MPs', European Journal of Turkish

Studies, Thematic Issue N³, Being a MP in contemporary Turkey, URL : http://www.ejts.org/document499.html

To quote a passage, use paragraph (§).

interests than with individual demands, which in a sense makes them more dependent on their parties.

\section{Conclusion}

[96] Different factors influence role-orientation of MPs, and there are sometimes contradictions between them, possibly resulting in role conflict. I found in my sample interesting cases of role distance, i.e. of deputies having to play roles that contradict their self-perceptions. We also found cases of role inadequacy, of MPs who, because of their resources and values, would not act according to an important part of the expectations toward them, like MP B with his constituents' demands. At the end of this exploratory study, I cannot put directly in relation with one another the different factors which would to build coherent profiles. To be able to develop a model of precise roles, better and more systematic data than those currently available are needed.

[97] In the meantime, I would assert, as this study shows, that role orientation is very much constrained by the resources of MPs. Now, how should a hierarchy of factors be framed? At which point do an MP's personal preferences begin to shape central elements of his role as a representative? Are institutional factors or individual resources more important for determining the role orientation? It seems that the relationship with the party does strongly influence positions, strategies and abilities of MPs, therefore role-orientation.

[98] Finally, there seem to be a role specialisation process, driven both by parties and by MPs themselves. Parties play a crucial role in the selection of political personnel, since they value different profiles, skills, and resources of MPs: they need connections with the masses, public representatives to have a good image, specialists in negotiation; they divide parliamentary labour accordingly. Our hypothesis is that through these processes there is a partial and selective professionalisation of political personnel. In order to check it, it would be interesting to relate MPs' longevity to the resources at their disposal. 
Citation: Massicard, Elise (2005) 'Differences in role orientation among Turkish MPs', European Journal of Turkish

Studies, Thematic Issue N³, Being a MP in contemporary Turkey, URL : http://www.ejts.org/document499.html

To quote a passage, use paragraph (§).

\section{References}

Abélès, Marc (2000) Un ethnologue à l'Assemblée, Paris, Odile Jacob.

Anadolu Haber Ajansı (2004) '22. dönem 2. yasama ylı çalışmaları sona erdi', 21/07/2004, URL: http://www.anadoluajansi.com.tr/index.php?option=com_content\&task=view\&id=47\&ltemid=90

Andeweg, Rudy B. (1997) 'Role Specialisation or Role Switching? Dutch MPs between Electorate and Executive' in Müller, Wolfgang C.; Saalfeld, Thomas (eds.), Members of Parliament in Western Europe. Roles and Behaviour, London, Frank Cass, pp. 110-127.

Aslan-Akman, Canan (2005) 'Being an opposition MP in the 22th Turkish Parliament', European Journal of Turkish Studies, Thematic Issue $\mathrm{N}^{\circ} 3$, Being a MP in contemporary Turkey, URL: http://www.ejts.org/document500.html

Bakırcı, Fahri (2000) TBMM'nin çalışma yöntemi, Istanbul, İmge.

Cotta, Maurizio; Best, Heinrich (2000) 'Between Professionalization and Democratization: A Synoptic View on the Making of the European Representative' in Best, Heinrich; Cotta, Maurizio (eds.), Parliamentary Representatives in Europe, 1848-2000. Legislative Recruitment and Careers in Eleven European Countries, Oxford, Oxford University Press, pp. 493-525.

Çitçi, Oya (1989) Yerel yönetimlerde temsil. Belediye örneği, Ankara, TODAiE.

Frey, Frederick W. (1965) The Turkish political elite, Cambridge, The M.I.T. Press.

Gençkaya, Ömer Faruk (2000) 'Milletvekilleri ve Parti Örgütü lilşkileri Saha Araştırması', in Çarkoğlu, Ali (derl.), Siyasi Partilerde Reform, Istanbul, TESEV, 2000, pp. 235-271.

Günay, Çimen (2005) 'Taking up the Gauntlet: Fictionists in the Turkish Parliament', European Journal of Turkish Studies, Thematic Issue $\mathrm{N}^{\circ} 3$, Being a MP in Turkey, URL: http://www.ejts.org/document473.html

Güneş-Ayata, Ayşe (1994) 'Roots and Trends of Clientelism in Turkey' in Güneş-Ayata, Ayşe; Roniger, Luis (eds.), Democracy, Clientelism and Civil Society, Boulder, Rienner, pp. 49-63.

Hazama, Yasushi (2005) 'Constituency Service in Turkey: a Survey on MPs', European Journal of Turkish Studies, Thematic Issue $\mathrm{N}^{\circ} 3$, Being a MP in contemporary Turkey, URL: http://www.ejts.org/document471.html

Herzog, Dietrich (1990) 'Der moderne Berufspolitiker: Karrierebedingungen und Funktion in westlichen Demokratien' in Wehling, Hans-Georg (Hrsg.), Eliten in der Bundesrepublik Deutschland, Stuttgart, Kohlhammer, pp. 28-51.

Kalaycıoğlu, Ersin (1988) 'The 1983 Parliament in Turkey: Changes and Continuities' in Heper, Metin; Evin, Ahmet (eds.), State, Military and Politics in Turkey, Berlin / New York, de Gruyter, pp. 4765.

Kalaycıoğlu, Ersin (1995) 'The Turkish Grand National Assembly: A Brief Inquiry into the Politics of Representation in Turkey' in Balım, Çiğdem; Kalaycıoğlu, Ersin; Karataş, Cevat; Winrow, Gareth; Yasamee, Feroz (eds.), Turkey: Political, Social and Economic Challenges in the 1990s, Leiden, Brill, pp. 42-60. 
Citation: Massicard, Elise (2005) 'Differences in role orientation among Turkish MPs', European Journal of Turkish

Studies, Thematic Issue N³, Being a MP in contemporary Turkey, URL : http://www.ejts.org/document499.html

To quote a passage, use paragraph (§).

Kocaoğlu, Emre (2003) Sözum Meclisten içeri. Acemi milletvekilinin Ankara anıları, Istanbul, Iyiadam.

Lacam, Jean-Patrice (1988) 'Le politicien investisseur. Un modèle d'interprétation de la gestion des ressources politiques', Revue française de science politique, 38(1), pp. 23-47.

Lagroye, Jacques (1994) 'Être du metier', Politix 28, 'Le métier d'élu - jeux de rôles', pp. 5-15.

Massicard, Elise (2003) Les élections du 3 novembre 2002 : un renouveau de la vie politique turque? Istanbul, Les dossiers de l'IFEA n¹5, URL: http://www.ifea-istanbul.net/publi/dossiers/dossier15.pdf

Merton, Robert K. (1957) Social Theory and Social Structure, revised and enlarged edition, New York, Free Press.

Nay, Olivier (2003) 'Le travail politique à l'assemblée. Note sur un champ de recherche trop longtemps déserté', Sociologie du travail 45, pp. 537-554.

Norton, Philip (1997) 'Roles and Behaviour of British MPs' in Müller, Wolfgang C.; Saalfeld, Thomas (eds.), Members of Parliament in Western Europe. Roles and Behaviour, London, Frank Cass, pp. 17-31.

Norton, Philip; Wood, D. M. (1993) Back from Westminster. British Members of Parliament and their Constituents, Lexington, University Press of Kentucky.

Patzelt, Werner J. (1997) 'German MPs and their Roles' in Müller, Wolfgang, C.; Saalfeld, Thomas (eds.), Members of Parliament in Western Europe. Roles and Behaviour, London, Frank Cass, pp. 55-78.

Saalfeld, Thomas (1997) 'The Professionalisation of Parliamentary Roles in Germany: An AggregateLevel Analysis, 1949-94' in Müller, Wolfgang C.; Saalfeld, Thomas (eds.), Members of Parliament in Western Europe. Roles and Behaviour, London, Frank Cass, pp. 32-54.

Searing, Donald D. (1994) Westminster's world. Understanding Political Roles, Cambridge, Harvard University Press.

Tachau, Frank (1988) 'Political Leadership in Turkey: Continuity and Change' in Heper, Metin; Evin, Ahmet (eds.), State, Military and Politics in Turkey, Berlin / New York, de Gruyter, pp. 103-117.

Tachau, Frank; Good, Mary-Jo D. (1973) 'The Anatomy of Political and Social Change: Turkish Parties, Parliaments, and Elections', Comparative Politics, 5(4), pp. 551-573.

(1983) T.C. Parlamenterler Ansiklopedisi, Ankara, Yankı-Pamukbank yayını.

Tuncer, Erol (2002) Osmanlı'dan günümüze seçimler, 1877-1999, Ankara, TESAV.

Turan, Ilter (1985) 'Changing Horse in the Midstream: Party Changes in the Turkish National Assembly', Legislative Studies Quarterly 10, pp. 21-34.

Wahlke, John C.; Eulau, Heinz; Buchanan, William; Ferguson, LeRoy C. (1962) The Legislative System: Explorations in Legislative Behaviour, New York, Wiley. 
Citation: Massicard, Elise (2005) 'Differences in role orientation among Turkish MPs', European Journal of Turkish

Studies, Thematic Issue N³, Being a MP in contemporary Turkey, URL : http://www.ejts.org/document499.html

To quote a passage, use paragraph (§).

\begin{tabular}{|c|c|c|c|c|c|c|c|c|}
\hline & Legislature & Party & Profession & $\begin{array}{l}\text { Duration of party } \\
\text { membership } \\
\text { before election }\end{array}$ & $\begin{array}{l}\text { Responsibilities in } \\
\text { party group during } \\
\text { legislature }\end{array}$ & \begin{tabular}{|l|} 
Ministerial \\
experience
\end{tabular} & Constituency & Committee \\
\hline A & 20 & $\begin{array}{l}\text { SHP } \\
\text { (power) }\end{array}$ & Engineer & 16 years & Party board & Yes & $\begin{array}{l}\text { East-Central } \\
\text { Anatolia } \\
\text { Was born and had } \\
\text { lived and worked in } \\
\text { constituency for a } \\
\text { long time }\end{array}$ & $\begin{array}{l}1 \& 2 \text { Public works; } \\
\text { European Economic } \\
\text { Community }\end{array}$ \\
\hline B & 21 & $\begin{array}{l}\text { DSP } \\
\text { (power) }\end{array}$ & $\begin{array}{l}\text { Doctor } \\
\text { (continues } \\
\text { partly during } \\
\text { mandate) }\end{array}$ & 0 year & No & No & $\begin{array}{l}\text { East-Central } \\
\text { Anatolia } \\
\text { Was born and had } \\
\text { in part grown up in } \\
\text { constituency, but } \\
\text { had hardly lived } \\
\text { there }\end{array}$ & $\begin{array}{l}\text { 1. Foreign Affairs } \\
\text { 2. No permanent } \\
\text { committe }\end{array}$ \\
\hline C & 21 & $\begin{array}{l}\text { ANAP } \\
\text { (power) }\end{array}$ & $\begin{array}{l}\text { Trade- } \\
\text { unionist }\end{array}$ & $\begin{array}{l}8 \text { years } \\
\text { Provincial vice- } \\
\text { chairman }\end{array}$ & $\begin{array}{l}\text { Member of the party } \\
\text { discipline committee }\end{array}$ & No & $\begin{array}{l}\text { Istanbul } \\
\text { Was not born in } \\
\text { constituency, but } \\
\text { had lived there } \\
\text { during a decades } \\
\text { before election }\end{array}$ & $\begin{array}{l}1 \& 2 \text { Health, Family, } \\
\text { Labour and Social } \\
\text { Affairs } \\
\text { (spokesperson); } \\
\text { Human Rights } \\
\text { (vice-chairman); } \\
\text { European Union } \\
\text { Integration }\end{array}$ \\
\hline D & 22 & $\begin{array}{l}\text { CHP } \\
\text { (opposi } \\
\text { tion) }\end{array}$ & $\begin{array}{l}\text { Trade- } \\
\text { Unionist }\end{array}$ & $\begin{array}{l}6 \text { years } \\
\text { Had been a } \\
\text { member of a party } \\
\text { abroad since } 31 \\
\text { years before }\end{array}$ & $\begin{array}{l}\text { Member of the party } \\
\text { assembly }\end{array}$ & No & $\begin{array}{l}\text { Istanbul } \\
\text { Was not born in } \\
\text { constituency and } \\
\text { had never lived or } \\
\text { worked there before } \\
\text { election }\end{array}$ & $\begin{array}{l}1 \& 2 \text { No permanent } \\
\text { committee, but } \\
\text { European working } \\
\text { groups }\end{array}$ \\
\hline $\mathbf{E}$ & 22 & $\begin{array}{l}\text { CHP, } \\
\text { indepe } \\
\text { ndant, } \\
\text { other } \\
\text { party }\end{array}$ & $\begin{array}{l}\text { Farmer } \\
\text { (continues } \\
\text { during } \\
\text { mandate) }\end{array}$ & 6 years & No & No & $\begin{array}{l}\text { South-Eastern } \\
\text { Anatolia } \\
\text { Was born, has } \\
\text { grown up and } \\
\text { worked in } \\
\text { constituency }\end{array}$ & $\begin{array}{l}\text { 1. Petition (not } \\
\text { wished) } \\
\text { 2. vice-chairman of } \\
\text { committee }\end{array}$ \\
\hline$F$ & 22 & $\begin{array}{l}\text { CHP } \\
\text { (opposi } \\
\text { tion) }\end{array}$ & $\begin{array}{l}\text { High } \\
\text { bureaucrat }\end{array}$ & $\begin{array}{l}3 \text { years - he was } \\
\text { contacted to run for } \\
\text { the } 1999 \text { elections }\end{array}$ & $\begin{array}{l}\text { Party executive } \\
\text { committee until } \\
\text { 2003; then member } \\
\text { of the party } \\
\text { assembly }\end{array}$ & No & $\begin{array}{l}\text { Istanbul } \\
\text { Was not born in } \\
\text { constituency, but } \\
\text { had worked there } \\
\text { during } 12 \text { years } \\
\text { before election } \\
\end{array}$ & $\begin{array}{l}\text { 1. No permanent } \\
\text { committee } \\
\text { 2. Plan and Budget }\end{array}$ \\
\hline G & 22 & $\begin{array}{l}\text { CHP } \\
\text { (opposi } \\
\text { tion) }\end{array}$ & Lawyer & $\begin{array}{l}35 \\
\text { Has been provincial } \\
\text { chairman many } \\
\text { times, and member } \\
\text { of the party } \\
\text { executive } \\
\text { committee before }\end{array}$ & No & No & $\begin{array}{l}\text { Mediterranean } \\
\text { Was born, has in } \\
\text { part grown up and } \\
\text { always worked in } \\
\text { constituency }\end{array}$ & $\begin{array}{l}\text { 1. Justice } \\
\text { 2. Constitution }\end{array}$ \\
\hline $\mathrm{H}$ & 22 & $\begin{array}{l}\text { CHP } \\
\text { (opposi } \\
\text { tion) }\end{array}$ & Lawyer & 0 year & No & No & $\begin{array}{l}\text { South-Central } \\
\text { Anatolia } \\
\text { Was born, has } \\
\text { grown up and }\end{array}$ & $\begin{array}{l}\text { 1\&2 Constitution } \\
\text { committee }\end{array}$ \\
\hline
\end{tabular}


Citation: Massicard, Elise (2005) 'Differences in role orientation among Turkish MPs', European Journal of Turkish Studies, Thematic Issue N³, Being a MP in contemporary Turkey, URL : http://www.ejts.org/document499.html To quote a passage, use paragraph (§).

\begin{tabular}{|c|c|c|c|c|c|c|c|c|}
\hline & & & & & & & $\begin{array}{l}\text { always worked in } \\
\text { constituency }\end{array}$ & \\
\hline I & 22 & $\begin{array}{l}\text { AKP } \\
\text { (power) }\end{array}$ & Academic & 1 year & $\begin{array}{l}\text { Party ombudsman } \\
\text { at the beginning of } \\
\text { legislature }\end{array}$ & No & $\begin{array}{l}\text { Istanbul } \\
\text { Was not born there, } \\
\text { but has lived and } \\
\text { worked there for } \\
\text { decades before } \\
\text { election }\end{array}$ & $\begin{array}{l}1 \& 2 \text { Committee } \\
\text { chairman }\end{array}$ \\
\hline$J$ & 22 & $\begin{array}{l}\text { AKP } \\
\text { (power) }\end{array}$ & Lawyer & 1 year & $\begin{array}{l}\text { Member of the party } \\
\text { national executive } \\
\text { committee }\end{array}$ & Yes & $\begin{array}{l}\text { Istanbul } \\
\text { Was not born there, } \\
\text { but has lived there } \\
\text { for fourteen years } \\
\text { before election }\end{array}$ & $\begin{array}{l}\text { 1. Justice } \\
\text { 2. Constitution }\end{array}$ \\
\hline K & $\begin{array}{l}22,5 \text { other } \\
\text { legislatures } \\
\text { before; } \\
\text { experience in } \\
\text { local } \\
\text { government }\end{array}$ & $\begin{array}{l}\text { AKP } \\
\text { (power) } \\
\text { Other } \\
\text { parties } \\
\text { before, } \\
\text { both } \\
\text { majority } \\
\text { and } \\
\text { oppositi } \\
\text { on } \\
\end{array}$ & Lawyer & $\begin{array}{l}1 \text { year (AKP) but } \\
\text { other parties before } \\
15 \text { years between } \\
\text { first party } \\
\text { membership and } \\
\text { first election as MP } \\
\text { Has been provincial } \\
\text { party leader }\end{array}$ & $\begin{array}{l}\text { Yes, in former party } \\
\text { and legislature } \\
\text { Responsibility in } \\
\text { political group in } \\
\text { former legislature }\end{array}$ & $\begin{array}{l}\text { Yes, three } \\
\text { times in } \\
\text { former } \\
\text { legislatures }\end{array}$ & $\begin{array}{l}\text { Black Sea } \\
\text { Was not born there } \\
\text { (but in neighbouring } \\
\text { province), but has } \\
\text { worked there during } \\
\text { decades }\end{array}$ & $\begin{array}{l}1 \& 2 \text { Committee } \\
\text { Chairman }\end{array}$ \\
\hline L & $\begin{array}{l}22 \text {, one other } \\
\text { legislature } \\
\text { before }\end{array}$ & $\begin{array}{l}\text { AKP } \\
\text { (power) } \\
\text { Elected } \\
\text { MP of } \\
\text { another } \\
\text { party } \\
\text { before, } \\
\text { in } \\
\text { power } \\
\text { for } \\
\text { some } \\
\text { time }\end{array}$ & Doctor & $\begin{array}{l}1 \text { year (AKP) } \\
\text { Other party } \\
\text { membership before } \\
\text { (about } 10 \text { years) } \\
\text { About } 4 \text { years } \\
\text { between first party } \\
\text { membership and } \\
\text { first election }\end{array}$ & $\begin{array}{l}\text { Has been member } \\
\text { of a group } \\
\text { leadership in } \\
\text { previous legislature }\end{array}$ & No & $\begin{array}{l}\text { North-Eastern } \\
\text { Anatolia } \\
\text { Was born in } \\
\text { constituency, has } \\
\text { grown up in part } \\
\text { there, but has } \\
\text { moved out for } \\
\text { university and has } \\
\text { never returned } \\
\text { there }\end{array}$ & $\begin{array}{l}\text { 1. \& 2. Plan and } \\
\text { Budget }\end{array}$ \\
\hline M & 22 & $\begin{array}{l}\text { AKP } \\
\text { (power) }\end{array}$ & $\begin{array}{l}\text { Businessma } \\
\mathrm{n}\end{array}$ & $\begin{array}{l}1 \text { year (AKP) } \\
\text { Other party } \\
\text { membership before } \\
\text { during } 3 \text { years }\end{array}$ & $\begin{array}{l}\text { Party provincial } \\
\text { vice-chairman } \\
\text { Had been a } \\
\text { member of the } \\
\text { provincial board of } \\
\text { another party before } \\
(1998-2001)\end{array}$ & No & $\begin{array}{l}\text { North-Central } \\
\text { Anatolia } \\
\text { Was born in } \\
\text { constituency, has } \\
\text { grown up in part } \\
\text { there, has lived and } \\
\text { worked there. }\end{array}$ & $\begin{array}{l}\text { 1. No permanent } \\
\text { committee but } \\
\text { specialized working } \\
\text { group in party } \\
\text { headquarters } \\
\text { 2. Plan -Budget }\end{array}$ \\
\hline
\end{tabular}


Citation: Massicard, Elise (2005) 'Differences in role orientation among Turkish MPs', European Journal of Turkish Studies, Thematic Issue N³, Being a MP in contemporary Turkey, URL : http://www.ejts.org/document499.html To quote a passage, use paragraph (§).

\section{Appendix 2: follow-up form of a political group for citizens' demands}

Tarih : / /

ILI

ILÇESI

$$
\text { ILÇEst : }
$$

\section{iŞ TAKIP FORMU}

\section{Gönderen Adı, Soyadı :}

İstek Sahibinin :

Adı, Soyadı

Görevi

Görev Yeri

Sicil No.

Adres ve Telefonu

isteĞi

$:$

İlgili Yer, Kişi ve Tel.

: ...........

YAPILAN işLEM

Tel. TBMM :

Adres:
Faks :

TBMM/ANKARA 